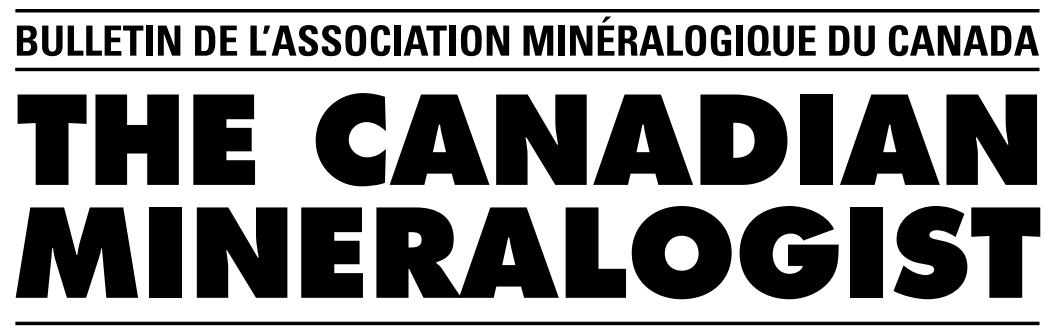

JOURNAL OF THE MINERALOGICAL ASSOCIATION OF CANADA

Volume 39

August 2001

Part 4

The Canadian Mineralogist

Vol. 39, pp. 937-956 (2001)

\title{
ORE-MINERAL TEXTURES AND THE TALES THEY TELL*
}

\author{
JAMES R. CRAIG ${ }^{\S}$ \\ Department of Geological Sciences, Virginia Polytechnic Institute and State University, \\ Blacksburg, Virginia 24060-0420, U.S.A.
}

\begin{abstract}
Ore minerals have been the resource base for all metal used by humankind since the dawn of history. Total world production of refined metals has been approximately 62 billion tonnes, and today, annual production exceeds 1.3 billion tonnes. Ore minerals, whether concentrated in ore deposits or dispersed as accessory minerals, can provide valuable information on the origins, histories and, in some case, futures of the metals. The same metals that serve society in myriad uses also have the potential to become major pollutants if released into the environment by combustion or weathering. The textures preserve a record of the means by which the minerals formed, provide insights as to the effective means of extracting the metals, and yield clues as to the future release of some metals. Each texture tells a tale with regard to origin, use, and future of the metal-bearing phases. Understanding these tales requires careful sampling, preparation, analysis, and interpretation. The techniques of analysis and interpretation of ore minerals may also be applied to such anthropogenic materials as artifacts and potential pollutants.
\end{abstract}

Keywords: ore minerals, textures, metals, ore microscopy.

SOMMAIRE

Les minéraux des minerais ont servi de ressource de base pour tous les métaux utilisés par l'homme depuis le début de l'histoire. Jusqu'à maintenant, la production mondiale totale de métaux affinés atteint environ 62 milliards de tonnes, et de nos jours, la production annuelle dépasse 1,3 milliards de tonnes. Qu'ils soient concentrés dans des gisements ou bien dispersés sous forme d'accessoires, les minéraux des minerais peuvent fournir une information précieuse à propos de l'origine, l'évolution et, dans certains cas, le sort éventuel des métaux. Les mêmes métaux qui sont bénéfiques à la société par leurs applications multiples peuvent devenir de véritables agents de pollution s'ils sont mobilisés dans l'environnement par combustion ou lessivage. Les textures conservent les vestiges du mode de formation des minerais, fournissent de l'information très utile pour faciliter l'extraction des métaux, et révèlent des indications à propos de l'instabilité éventuelle de ceux-ci. Chaque texture contribue à l'histoire d'un assemblage, et fournit des indices à propos de son origine, son utilisation, et la stabilité éventuelle des phases porteuses des métaux. Pour bien pouvoir comprendre ces indices, il faut un échantillonnage soigné, une préparation des échantillons, une analyse appropriée et une interprétation. Les mêmes techniques d'analyse et d'interprétation s'appliquent aux matériaux anthropogéniques, tels les objets fabriqués et les matières polluantes.

(Traduit par la Rédaction)

Mots-clés: minéraux des minerais, textures, métaux, microscopie en lumière réfléchie.

* This contribution represents an outgrowth of a plenary address delivered at the seventeenth General Meeting of the International Mineralogical Association in Toronto (1998).

§ E-mail address: jrcraig@vt.edu 


\section{INTRODUCTION}

Ore minerals, those metal-bearing minerals that we can either use directly for their metal content (such as native copper) or from which we can extract metals through a variety of processes, have served humankind beneficially for more than 10,000 years. Throughout history, humans have refined a total of approximately 62 billion tonnes of metals and are currently producing more than 1.3 billion tonnes of metal per year (Craig 2001, U.S. Geological Survey 1999). However, ore minerals are not just valuable as sources of metals; these minerals may also be viewed as environmental pollutants responsible for the generation of acid mine-waste runoff, for production of acid rain, and for the release of various toxic metals into the environment. Metals may be released during weathering of ore minerals, during combustion of coal that contains metal-bearing minerals, or as losses during smelting processes (such as recently documented losses of copper, nickel and other metals from smelters in the Norils'k area in Russia by Stumpfl et al. 1997). Furthermore, metallic minerals may be generated as products of corrosion on, and in some cases cause the destruction of, human structures and artifacts; such materials are well known to archeologists who have encountered them as coatings on metallic implements (Scott 1991).

\section{The Tales That Ore Minerals Can Tell}

Ore minerals, whether in economic deposits or dispersed in non-economic concentrations, provide evidence of geological processes active in the past. If one views formations and deposits (veins, massive sulfides, etc.) as pages of a book, the ore minerals may be viewed as words on the page, revealing information on their origin and their life history. In some instances, the words are clear and straightforward, but in other contexts they are much more like crossword puzzles or ciphers. Edgar Allen Poe's "The Gold Bug" is a story in which it is necessary to solve a cipher in order to locate a buried golden treasure; in a similar manner, the textures of the ore minerals (and many minerals as well) may be read as ciphers that can offer information on the location and nature of treasures of gold and other metals. Paul Barton (1991) has noted that "ore deposits are among the most complex inorganic features of our planet." In his insightful work, he goes on to state that "the interpretation of textures is one of the most difficult, yet important, aspects of the study of rocks and ores, and there are few areas of scientific endeavor that are more subject to misunderstanding." Furthermore, the "ore minerals" (roughly synonymous with "opaque minerals") are integral, if minor, components of many types of rocks, and provide potential petrogenetic information there as well as in ore deposits. Geologists tend to think of the tales in rocks and minerals as only those from the past. However, the high reactivity of some ore minerals en- sures that they have predictable futures in terms of weathering, to form new phases and to release metals.

\section{Identifications and textures}

The two most important aspects of petrography are (i) the identification of the minerals, and (ii) the interpretation of textures. Much mineral identification has now become routine with the ready access to X-ray diffraction, scanning electron microscopes, electron microprobes, etc. However, although these commonly make identification relatively simple, their routine use has reduced some of the careful optical examination, which included the subtle characteristics and textures that were used to identify minerals in the past.

The word "texture" is derived from the Latin word textura, meaning "web" or texto, meaning "to weave". Hence, the textures that we see, examine, and try to interpret are the very fabrics and the essential parts that make up the materials. Textures range in scale from megascopic to ultra-microscopic, and it has become increasingly apparent that it is necessary to examine samples over a range of scales if one is to understand the information that is contained within the rocks. Invesitgators have applied a wide variety of approaches to the study of textures, thus expanding our understanding and ability to interpret them. Partictularly noteworhty are the works of Edwards (1946), Bastin (1950), Ramdohr (1969), Eldridge et al. (1983), Ixer (1990), Barton (1991), Craig (1991a, b) and Craig \& Vaughan (1994).

Despite a significant increase in our understanding of ore-mineral textures, there are still many gaps in our knowledge. Many have speculated that the exhaustion of higher grade and more accessible metal ores will force future exploitation of lower grade, or more refractory ores. Successful exploitation of these ores will require greater efficiency in ore recovery, which, in turn, will require a better understanding of textures and their implications with regard to mineral separation. At the same time, increasing awareness and concern over heavy metals in the environment will require better textural analysis of the pollutants and their interactions with fluids and organisms.

Ore-mineral textures are of nearly endless varieties; each one presents a tale, but only some are decipherable, at least for the present. Space constraints preclude a comprehensive treatment, so in the present paper, I attempt to discuss only a few textures, which have fascinating tales to tell.

\section{Macroscale to Microscale - \\ Simple to CompleX - Natural to Anthropogenic}

Ore textures range from meters to micrometers in scale, and studies on all scales may be useful in deciphering the origin and post-formational history of a deposit. Conventional optical microscopy generally deals 
with samples over a range of perhaps five orders of magnitude, $10 \mathrm{~cm}$ to $1 \mu \mathrm{m}$. One can encounter larger grain-sizes, but they are uncommon in dealing with the ore minerals, and smaller grain-sizes require non-optical instruments such as the scanning electron microscope, electron microprobe or atomic-force microscope. Characterization at all scales is ideal because largerscale features commonly provide a context to help interpret smaller-scale features and vice versa. A good example of the extremes of scale is evident in the pyrite samples of Figure 1, where grain sizes range from about $10 \mathrm{~cm}$ to approximately $1 \mu \mathrm{m}$. It is important to note that the size of grains is vital in interpreting growth histories of ores and in predicting the degree of liberation and potential recovery of minerals during processing. The complexity of ores varies widely (Figs. 2a, b) and is rarely discernable to the naked eye, but can generally be determined rapidly using conventional reflected-light microscopy.

Nonterrestrial minerals and synthetic analogues of ore minerals are equally amenable to study and textural interpretation using reflected light microscopy. Whether it is a sample from the Moon (Fig. 3a) or an ancient Roman slag (Fig. 3b), the minerals and phases are identifiable and interpretable. The extension of ore micros-
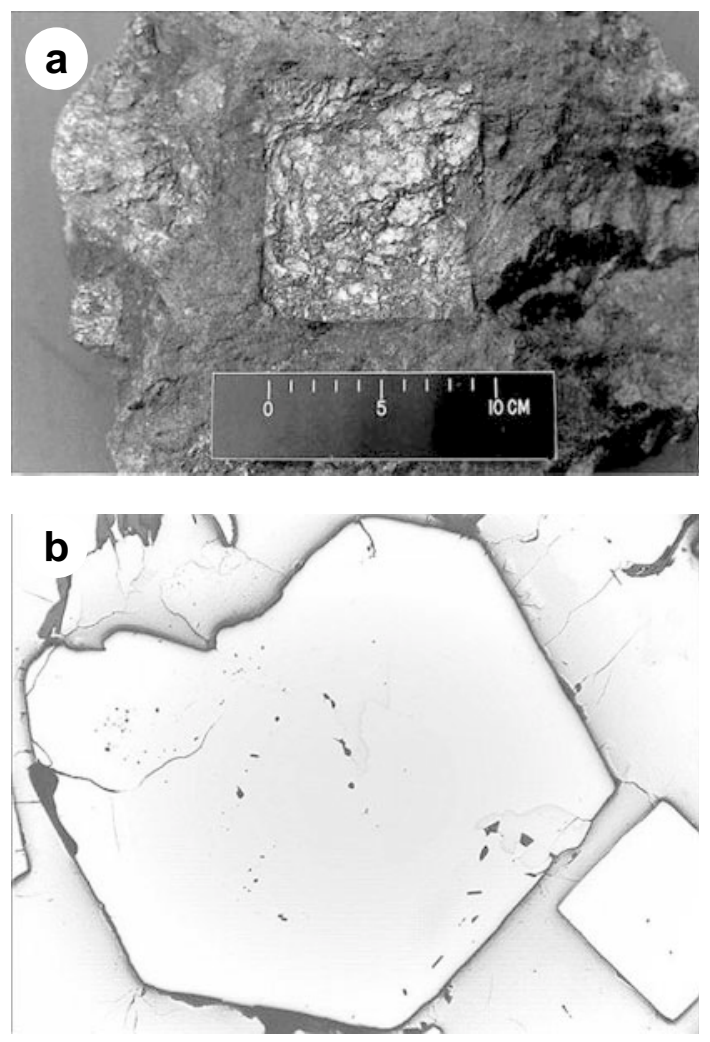

copy and textural analysis to anthropogenic materials immediately increases dependence upon analytical techniques, because human activities commonly bring together elements that do not have natural geochemical affinities.

\section{Intergranular relationships}

The relations of grains of various minerals in an ore can have profound effects upon the ease and completeness with which the minerals may be separated into mineral concentrates; such relations may also reveal a great deal about the origin of the ores and their postdepositional history. The first point is easily illustrated by comparison of the two samples shown in Figures 4a and $4 \mathrm{~b}$. The former shows a typical example of "chalcopyrite disease", in which finely dispersed grains of chalcopyrite and pyrrhotite are disseminated throughout sphalerite. This texture was long interpreted as resulting from exsolution of a previously existing single homogeneous phase that had undergone unmixing during cooling. However, it seems that there is not a single mechanism by which all samples of chalcopyrite disease have formed; instead, whereas coprecipitation and secondary alteration are responsible for many samples

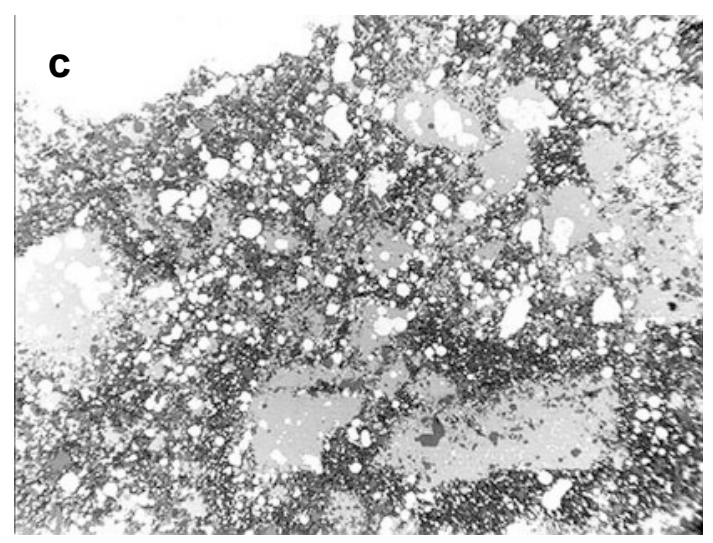

FIG. 1. The grain sizes of ore minerals vary over several orders of magnitude, as illustrated by pyrite, the most abundant of the sulfide minerals. The $10 \mathrm{~cm}$ pyrite crystal in (a) is approximately 100 times larger than the more typical 1 millimeter grains in (b), and 100,000 times larger than the $1 \mu \mathrm{m}$ grains in (c). The finest grain-sizes form typically under low-temperature conditions, whereas the largest grains form under higher-temperature and higher-pressure conditions. Samples shown in (a) and (b) are from Ducktown, Tennessee, and that in (c) is from McArthur River, Australia. 

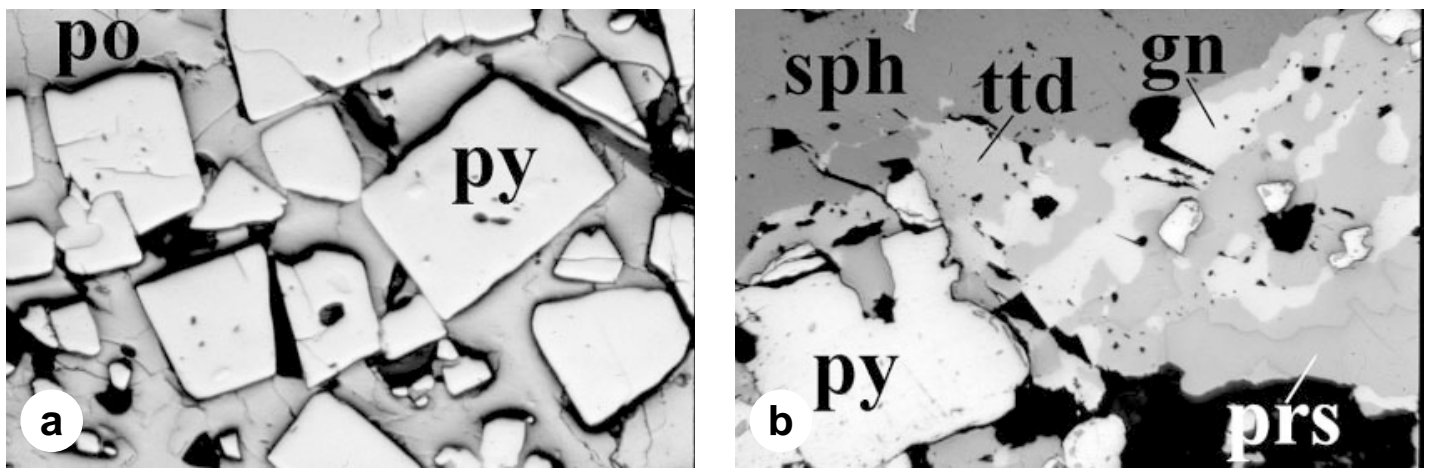

FIG. 2. The chemical complexity of the ore mineral assemblage varies widely from that of a simple two-component system (Fe and S) of pyrite (py) and pyrrhotite (po) in (a) to that of much more complex multicomponent systems (with at least Fe, Zn, $\mathrm{Cu}, \mathrm{Pb}, \mathrm{Sb}, \mathrm{As}, \mathrm{Ag}$, and S) of pyrite (py), sphalerite (sph), galena (gn), tetrahedrite (ttd), and proustite (prs), in (b). Provenance: (a) from Ducktown, Tennessee, (b) from Sombrete, Mexico. The widths of the fields of view are each $0.8 \mathrm{~mm}$.
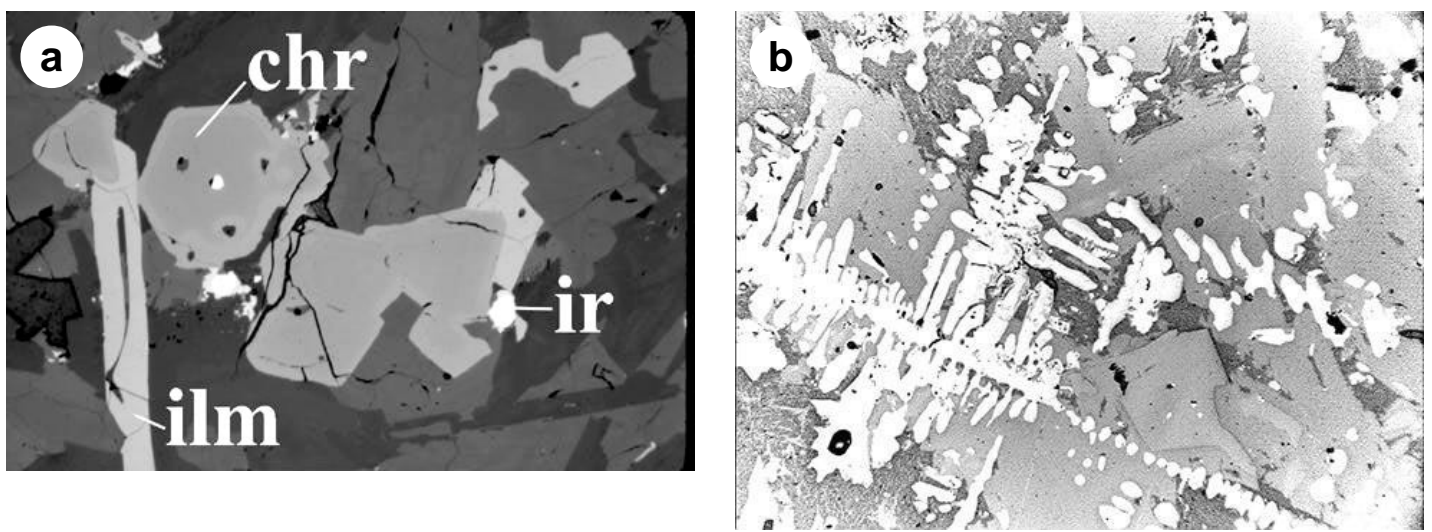

FIG. 3. The principles of textural interpretation apply to extraterrestrial samples (a) and anthropogenic materials such as the slags (b) left by the Romans when they mined copper ores on Cyprus approximately 2000 years ago. In the lunar sample shown in (a), the equant grains of chromite (chr) are overgrown with a rim of ulvöspinel, attesting to changing conditions of availability of elements and oxygen activity in the lunar samples during their crystallization. The long, light-gray lath is ilmenite (ilm), and the bright white phase is native iron (ir), an indicator of the low level of oxygen fugacity. In (b), the skeletal and cruciform grains of magnetite, coexisting with minor pyrrhotite and chalcopyrite in the Roman slags, crystallized during the rapid cooling of the slag. The presence of chalcopyrite indicates that there was not complete recovery of the copper in the smelting process. The width of the field of view is $1.2 \mathrm{~mm}$ in (a) and $0.6 \mathrm{~mm}$ in (b).

(Barton \& Bethke 1987), exsolution also is responsible for at least some of the textures (Mizuta \& Scott 1997). Figure $4 \mathrm{~b}$, shown at the same magnification and with a quite similar bulk-ore composition as the material in Figure $4 \mathrm{a}$, is different in that it contains much larger grains that are virtually free of inclusions. Bulk chemical analysis of the two samples would give similar results; only careful textural examination reveals the differences that will be found in the concentrates.
Figures $5 \mathrm{a}$ and $5 \mathrm{~b}$ show gold-bearing ores that tell another tale of the potential for metal recovery. The gold in Figure 5a occurs as relatively large grains and lies along the boundaries between arsenopyrite and pyrrhotite. Even relatively limited milling of the ores would either liberate the grains of gold to allow gravitational separation, or expose the gold for easy dissolution by cyanide treatment. The gold in Figure $5 \mathrm{~b}$ is both much smaller and is held completely within pyrite. The same 

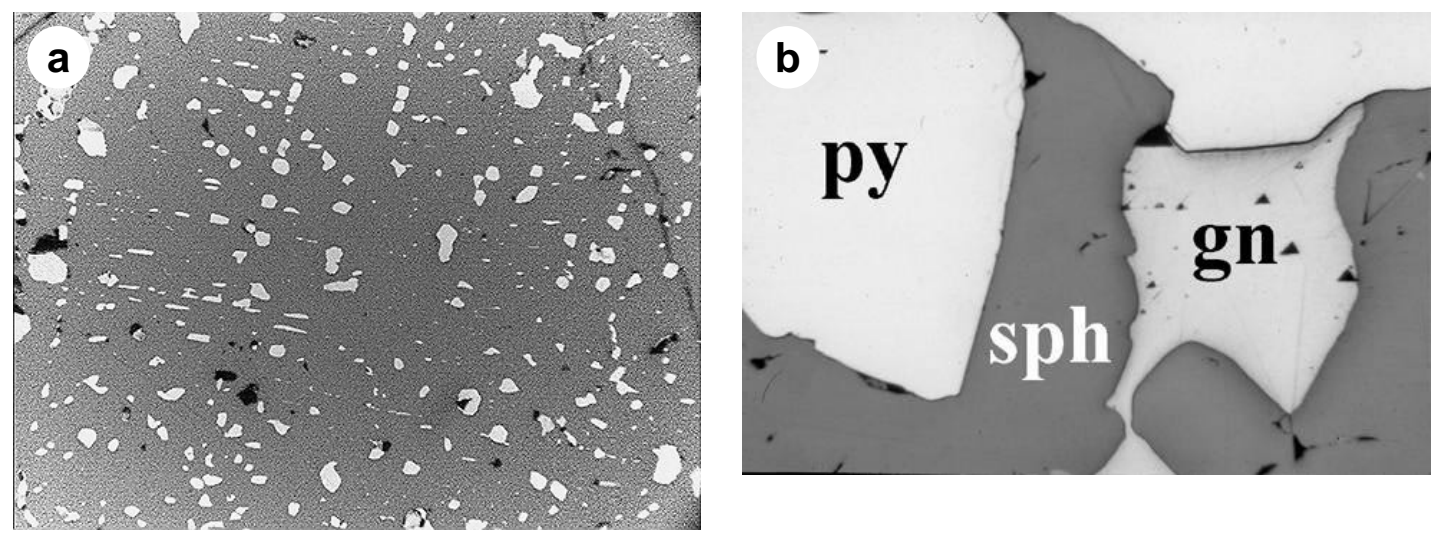

FIG. 4. The size of mineral grains and the intimacy of their intergrowth correlate well with the ease of recovery and purity of the concentrates of ore minerals. (a) The presence of chalcopyrite disease in a sample from Wheal Jane, Cornwall, U.K., may give information on the origin of the ores, and clearly indicates that it will be difficult, if not impossible, to prepare clean concentrates for copper and zinc. In contrast, the coarse-grained pyrite (py) - sphalerite (sph) - galena (gn) ore in (b), from the Black Angel mine, Greenland, will easily separate to yield clean concentrates of each mineral. For both samples, the field of view is $0.8 \mathrm{~mm}$.
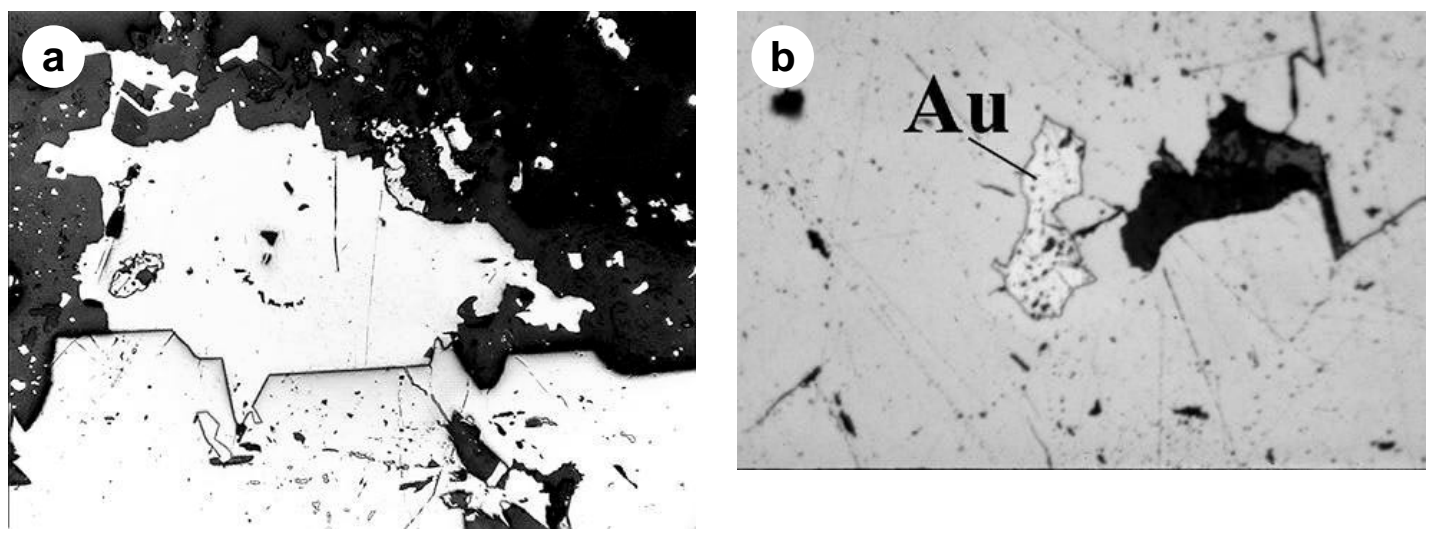

FIG. 5. Gold recovery is affected not only by grain size, but also by the location of the gold grains in the ore-mineral assemblage. The brighter grain of gold (a) from the Homestake mine, South Dakota, lies along the boundary of an arsenopyrite grain and quartz, where fracturing will readily release or expose it. In contrast, the fine grains of gold ( $\mathrm{Au}$ ) completely enclosed within the pyrite of the Haile mine, South Carolina, in (b) will be much more difficult to recover because they are not likely to be exposed by fracturing. The width of field for (a) is $0.8 \mathrm{~mm}$ and for (b) is $0.4 \mathrm{~mm}$.

degree of milling that would effectively expose the gold in Figure 5a would have a much lower likelihood of liberating or exposing the gold in this "refractory" ore; more milling is needed, or gold recovery will be significantly lower.

\section{Paragenetic interpretations}

Intergranular relations and textures may also yield considerable information on the paragenetic history of an ore; in some cases, single grains can yield considerable information. The sample of bravoite, in Figure 6, presents a textural record of the changing nature of the ore-forming fluid throughout the time of bravoite precipitation, in much the manner in which the growth rings in a tree record information about conditions of growth. Most grains of pyrite do not contain sufficient minor cations to reveal optical zonation as does bravoite, but some do still contain subtle growth-textures that can only be seen with careful use of etchants, as is illus- 


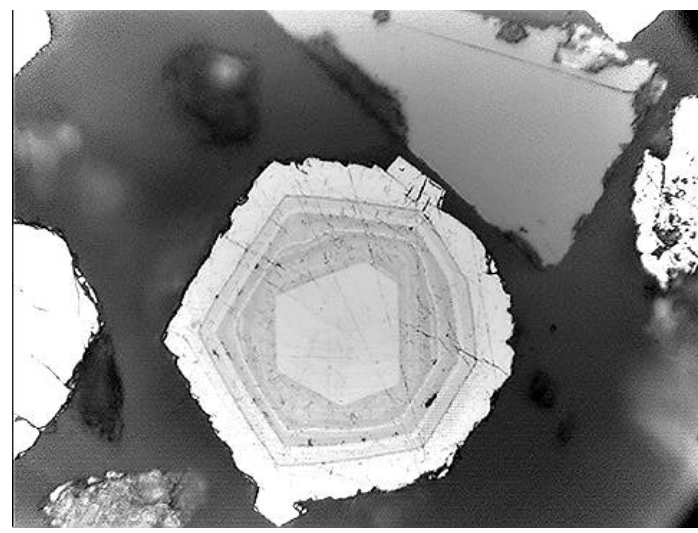

FIG. 6. Bravoite, such as this from Maubach, Germany, commonly contains a vivid record of growth histories in the purple-to-gray banding that results from the incorporation of cobalt and nickel available as they formed. The width of the field of view is $0.4 \mathrm{~mm}$.

trated in Figures $7 \mathrm{a}$ and $7 \mathrm{~b}$; the unetched grain shows only a faint suggestion of the growth pattern that was greatly enhanced by etching with hydrogen peroxide.

The examples cited above likely represent more-orless continuous deposition from solutions that were changing in terms of available metals and, possibly, temperature. In contrast, many ores bear testimony to precipitation from multiple generations of distinctly different fluids. Figure 8a shows the presence of a second episode of mineralization in which a cross-cutting vein of native silver was deposited after the initial phase of mineralization had deposited chalcopyrite and bornite. Similarly, Figure $8 \mathrm{~b}$, shows that a later generation of mineralizing fluid was responsible for the recrystallization of microcrystalline "gel pyrite" into larger grains of pyrite and marcasite, and the deposition of veinlets of cross-cutting siderite hosting gold.

\section{Internal change in texture}

Textural change associated with paragenetic change of the type described above accompanies changes in bulk compositions of ores, as new elements and minerals are introduced or removed. In contrast, some ore minerals undergo marked textural transformation, with no change in bulk chemical composition, merely as the result of re-equilibration during cooling. Among the best known is the exsolution of pentlandite from nickel-bearing monosulfide solid-solution (essentially a high-temperature pyrrhotite) in Sudbury-type magmatic nickel ores to form "flames" (Fig. 9a). Subsequent to early fine-scale exsolution, continued diffusion of nickel results in development of more-or-less continuous coarser-grained chains or veinlets of pentlandite at the margins of the host pyrrhotite. Another common
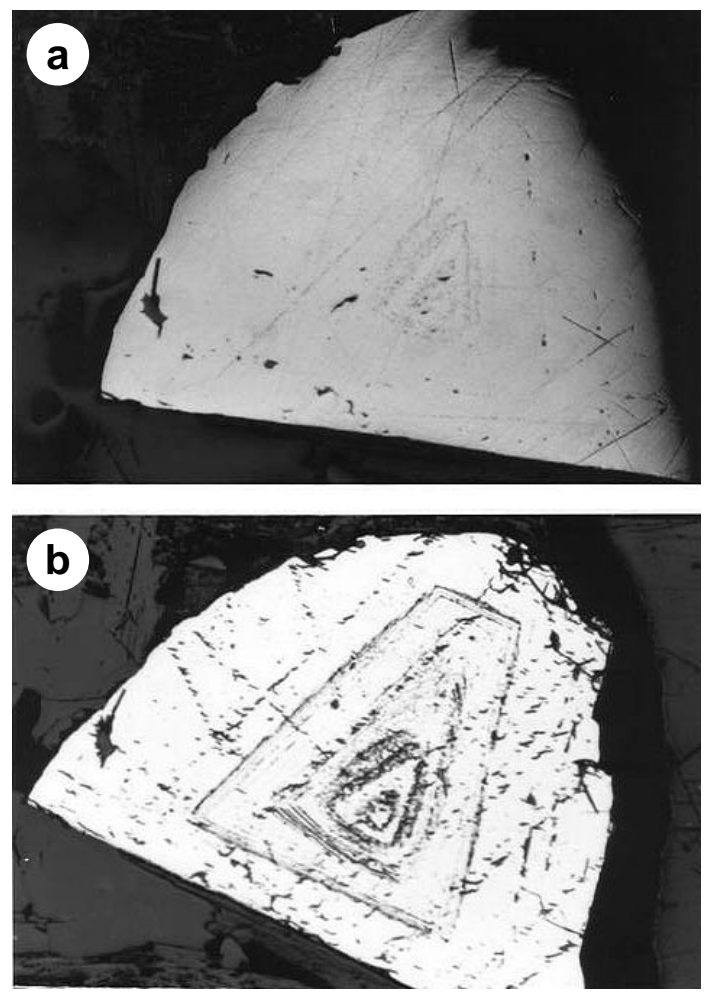

FIG. 7. In some cases, the information held in minerals is more easily exposed if the grains are etched. Etching of pyrite grains in (a) (with hydrogen peroxide) reveals welldeveloped growth banding in (b) that was only faintly visible during initial polishing. Minor differences in hardness, the number of structural defects in the mineral structure, and minor differences in chemical composition are often easily exploited by etchants to reveal otherwise invisible textures. The width of field of view is $1.2 \mathrm{~mm}$.

example of exsolution from a previous higher-temperature homogeneous phase is that of bornite and chalcopyrite (Fig. 10a). Attempts to quantify initial temperatures of formation or rates of cooling of this mineral assemblage on the basis of the lamellae have generally been unsuccessful, but the texture does show evidence of the pre-existing single phase. Among the oxide ore minerals, exsolution textures of iron and titanium oxides are probably the most common. Hematite and ilmenite form a continuous solid-solution series at high temperature, as do magnetite and ulvöspinel. Cooling may result in simple but characteristic exsolution of lenses of hematite and ilmenite (Fig. 10b) and, more rarely, thin lamellae of ulvöspinel from magnetite. The formation of ilmenite laths in magnetite (Fig. 10c) is a more complex tale in that it records oxidation of the titanium-bearing magnetite in order for the ilmenite to form (instead of ulvöspinel). 

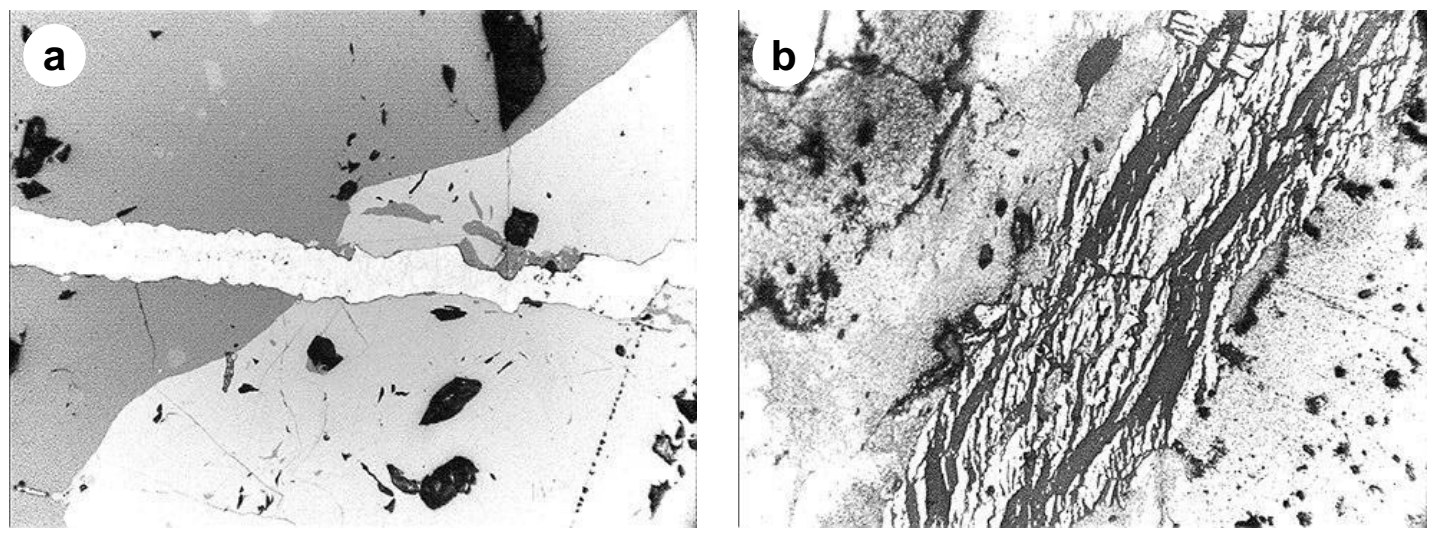

FIG. 8. Many ore minerals contain evidence of multiple episodes of formation. This is well illustrated in (a), where a later vein of native silver cross-cuts earlier bornite and chalcopyrite, and in (b), where later fluids followed fractures through a microcrystalline pyrite ("gel pyrite") and recrystallized the earlier pyrite into coarser pyrite and marcasite; the later veins are also filled with siderite and contain significant amounts of gold. Provenance: (a) from Sombrete, Mexico, and (b) from Mashan, China. The field of view is $1.2 \mathrm{~mm}$ in both images.
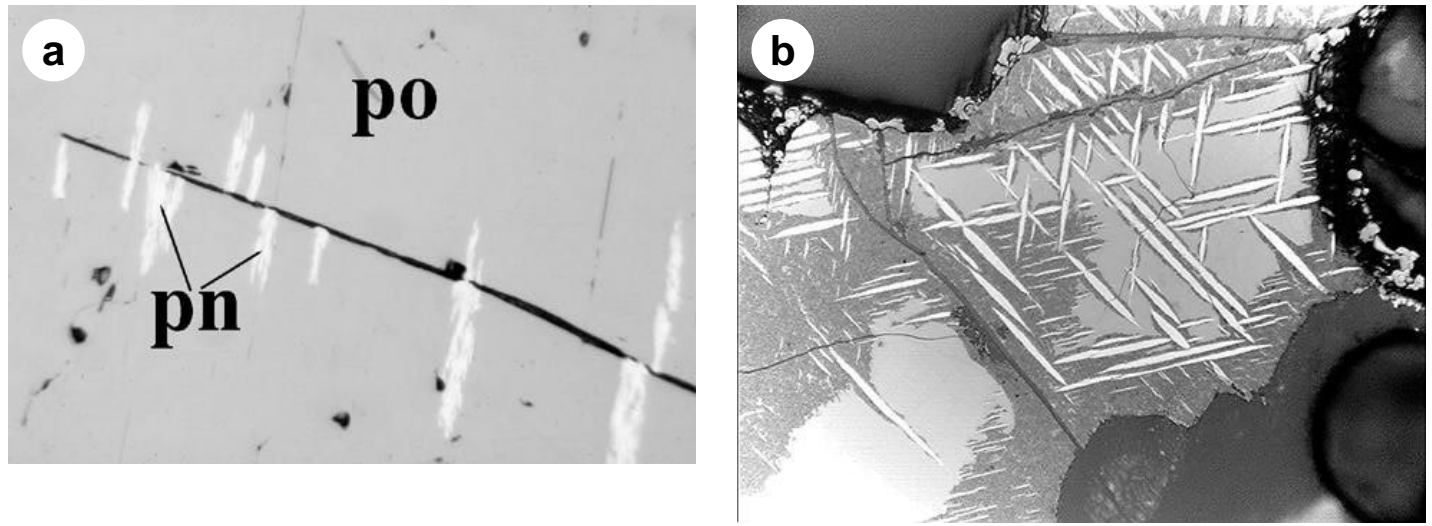

FIG. 9. Cooling of some high-temperature forms of minerals may result in solid-state exsolution. (a) Typical exsolution of pentlandite (pn) "flames" from pyrrhotite (po) in Sudbury-type nickel ores. (b) Exsolution of chalcopyrite laths from a preexisting high-temperature chalcopyrite-bornite solid solution. The darker gray zone around the margins indicates a later episode of oxidation, which removed copper from the bornite, forming digenite. Field of view is $0.8 \mathrm{~mm}$.

\section{Replacement and oxidation phenomena}

Studies of ore deposits have shown many times that ore-forming processes are commonly not single events, but rather result from a series of episodes of fluid mobility, transporting metals into (and possibly out of) small regions of the Earth's crust. Accordingly, many ores bear evidence of significant modification since the time of their formation. Figure 11a shows original wood structure that has been replaced sequentially by pyrite, now defining the open cellular structure, and chalcocite, now defining the intervening rigid cellulose, as fluids percolated through a typical "red-bed" copper deposit where buried organic matter was replaced through the action of low-temperature metal-bearing fluids. Figure $11 \mathrm{~b}$ shows pyrite that was deposited early in the formation of a skarn deposit, and then was nearly completely replaced by magnetite as later fluids became more oxidizing. Figure $11 \mathrm{c}$ shows a roughly equant grain of pyrite that was deposited by hydrothermal fluids, was subsequently fractured, and then was partially replaced by interaction with copper-rich fluids; these fluids deposited bornite around the pyrite crystal, but deposited only chalcopyrite in microenvironments within the py- 

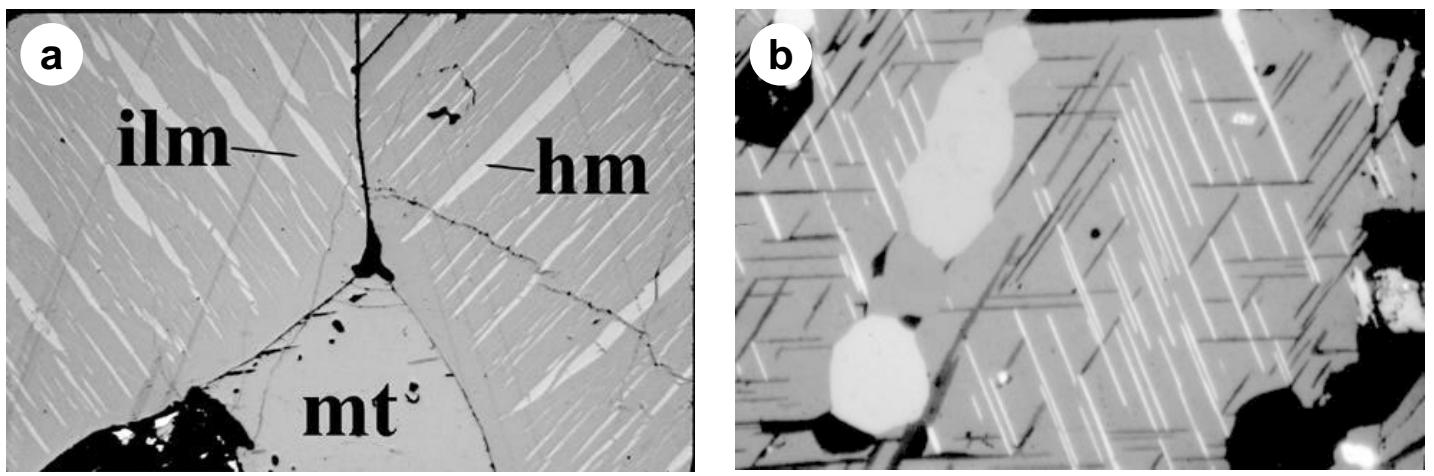

FIG. 10. Oxide minerals are commonly more refractory than sulfide minerals, but the high-temperature solid-solution between hematite (hm) (white lamellae) and ilmenite (ilm) commonly undergoes exsolution on simple cooling to create textures of the type shown in (a) . Compare this with Figure 12, where detrital grains retain the texture formed in the original primary minerals. The exsolution of ilmenite from magnetite in (b) indicates that some degree of oxidation must have occurred during the cooling episode. Provenance: (a) from Koldal, Norway, and (b) from Bausto, Norway. Width of field of view is $0.8 \mathrm{~mm}$ in both cases.
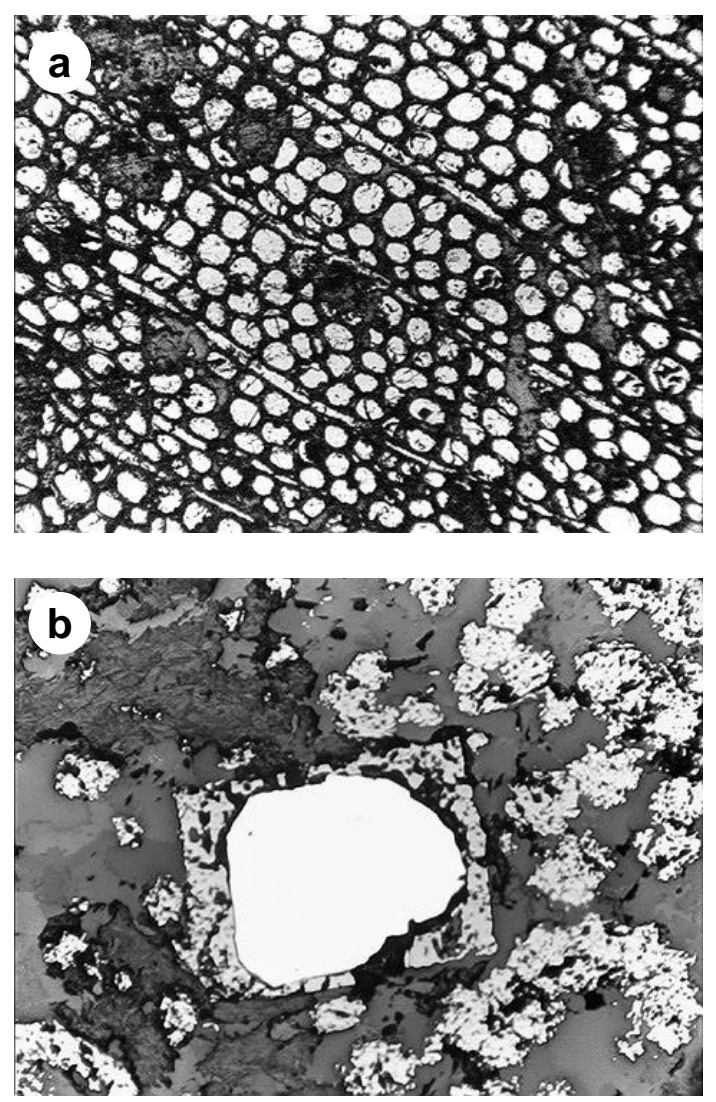

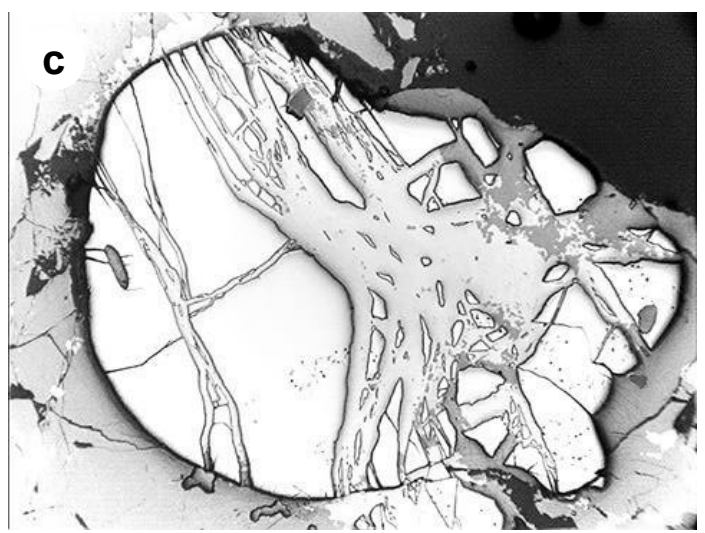

FIG. 11. Replacement reactions can occur under a broad range of conditions. Under near-surface conditions, wood structure in (a) has been replaced by pyrite in the cells and chalcocite between the cells. At higher temperature during skarn formation, pyrite grains in (b) have been partly replaced by magnetite. Under hydrothermal conditions, a fractured crystal of pyrite in (c) has been partially replaced by chalcopyrite and engulfed in bornite. Each texture records at least two episodes in the history of the deposits in terms of conditions and the nature of the initial and replacing fluids. Provenance: (a) from Nacimiento, New Mexico, (b) from Mashan, China, and (c) from Magma, Arizona. Width of field of view is $0.8 \mathrm{~mm}$ in each case. 
rite crystal, where the activities of iron and sulfur were maintained at much higher levels by the presence of the reacting pyrite.

Deciphering the tales told by replacement and oxidation textures requires both caution and special consideration of the spatial context, because the reactions are generally selective in the minerals affected and because the reactions commonly are localized within a deposit. This is commonly seen where oxidation affects only the shallower parts of orebodies. Less obvious, but also important, are replacement reactions that are localized in cases where later generations of ore-bearing fluids affect only certain parts of ore deposits. It is commonly presumed that oxidation of ores is generally detrimental because it alters the nature of the minerals and reduces either the metal content or makes recovery more difficult. Although oxidation has reduced the value of some ores, it has certainly enhanced the value of others by forming enriched supergene zones; this is especially true in many presently mined porphyry-copper ores. Oxidation also can play a role in the enhancement of sedimentary placer ores (Figs. 12a, b). Much of the titanium produced today is derived from sedimentary deposits that formed by accumulation of accessory ilmenite and rutile grains weathered out of igneous and metamorphic rocks. When first formed, many of these mineral grains had exsolution lamellae of hematite within ilmenite (Fig. 10a). During weathering, erosion, and transport of the grains, hematite, which has a higher solubility than ilmenite, is commonly preferentially removed. Some grains (Fig. 12a) still retain some of the original hematite in their core even though the hematite nearer the edges has largely been removed. Figure $12 b$ shows the complete removal of hematite, even though the texture retains evidence of its previous existence in the sample. Removal of hematite increases the value of the ore minerals because it results in a relative increase in the titanium content of the mineral grains.

\section{Deformation and metamorphism}

Many ore minerals have been subjected to thermal and deformational processes. In many instances, deformation and heating obliterate (or greatly attenuate) earlier textures that could have served in deciphering the genesis of the original ore. However, careful examination, especially of the more refractory minerals, may yield evidence of metamorphism and pre-metamorphic history of the ore. The response of individual ore minerals to deformation varies widely, depending on the conditions of deformation and on their own physical properties (e.g., pyrite is much harder than most other sulfides and withstands deformation, whereas softer minerals flow plastically or are dissolved by pressure solution). Kelly \& Clark (1975) showed that the strengths of several of the common sulfide minerals decrease significantly as temperature rises, making them more susceptible to plastic deformation at higher grades of metamorphism. More refractory sulfide and oxide minerals retain their strength in spite of rising temperature at most moderate metamorphic grades and are thus more likely to survive periods of deformation and to retain physical and chemical textures. In contrast, softer minerals, particularly sulfides, are more likely deform and hence erase original textures that had been preserved in them. Vokes (1969) introduced the wonderfully descriptive term of "Durchbewegung" to describe ore textures in which penetrative deformation has thoroughly kneaded the ore and completely obliterated any original textures.
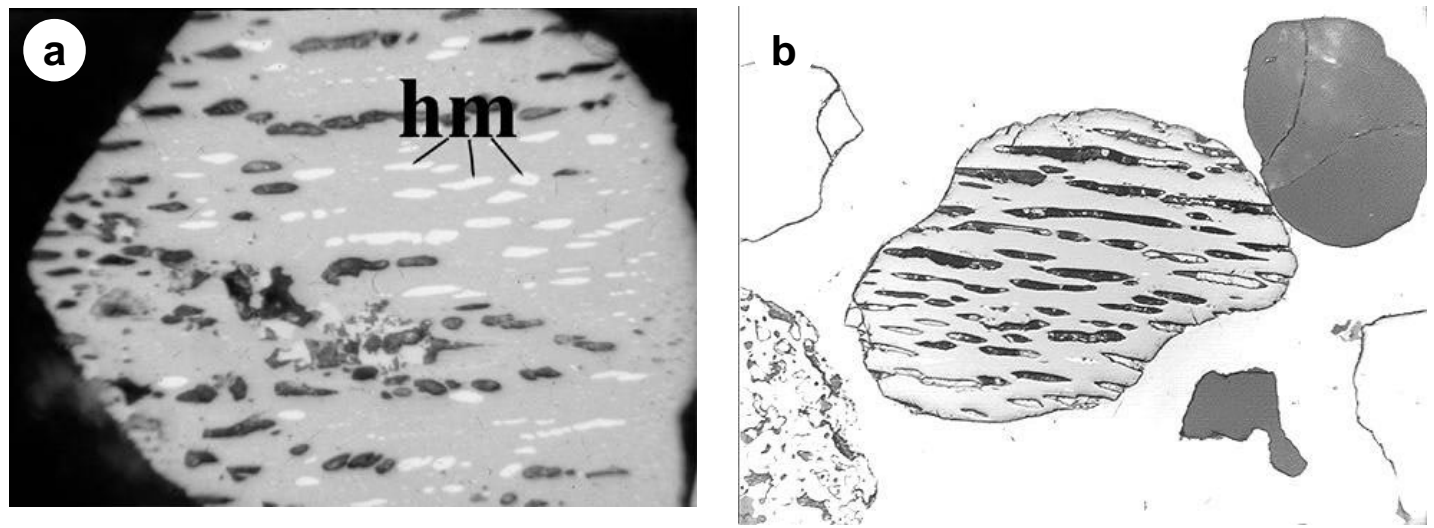

FIG. 12. The ilmenite grains that occur in placer titanium deposits commonly contain ilmenite-hematite exsolution intergrowths of the type shown in Figure 10. The weathering of these grains results in the selective removal of hematite as shown in (a) until the only evidence of the pre-existing hematite is the presence of voids that preserve the texture as shown in (b). The width of the field of view is $0.8 \mathrm{~mm}$ in each case. 
Just as ore minerals respond differently to deformation, so they respond differently to prolonged periods of heating, which can result in significant recrystallization. Barton (1970) presented a qualitative but highly informative diagram depicting general rates of equilibration of several ore minerals; it showed that equilibration is highly temperature-dependent and that, in general, more metal-rich sulfides (such as pyrrhotite or chalcocite) tend to equilibrate much more rapidly at any given temperature than do sulfur-rich sulfides (such as pyrite). Thermal recrystallization of polycrystalline masses commonly allows pyrite crystals to assume euhedral forms (Fig. 13a), whereas monomineralic masses tend to recrystallize with $120^{\circ}$ grain-boundaries. Oxide minerals, such as hematite (Fig. 13b) may be more resistant to recrystallization, but may still show evidence of deformation in the form of well-defined twin-lamellae. Although metal-rich sulfides tend to recrystallize rather easily, they may retain significant strain-induced features if they have not experienced metamorphic heating after deformation at relatively low temperature. Thus, a few grains of pyrrhotite retain welldeveloped kink-banding (Fig. 13c). The kink-banding occurs adjacent to a large grain of undeformed pyrite, which apparently served as a buttress around which the pyrrhotite deformed (the kink-banding is made more visible by the presence of thin zones of mica in the pyrrhotite).

\section{Pyrite and sphalerite}

Pyrite and sphalerite are singled out for special comment because each is very widespread and because each is well-known as having the propensity of incorporating significant amounts of elements and inclusions that might contribute to understanding their histories. Pyrite is the most widespread and common of the sulfide minerals because it is composed of the most widely available siderophile metal and is stable over a very wide range of temperature, pressure, and oxygen fugacity. Sphalerite is the principal ore mineral (usually the only one today) of zinc and is one of the most common of the base-metal sulfides, occurring in many ore deposits. In contrast to pyrite, which is readily recognized by its bright brassy metallic appearance and common cubic habit, sphalerite is often difficult to recognize and identify because it occurs in a broad spectrum of colors and rarely develops characteristic crystal habits. In fact, its
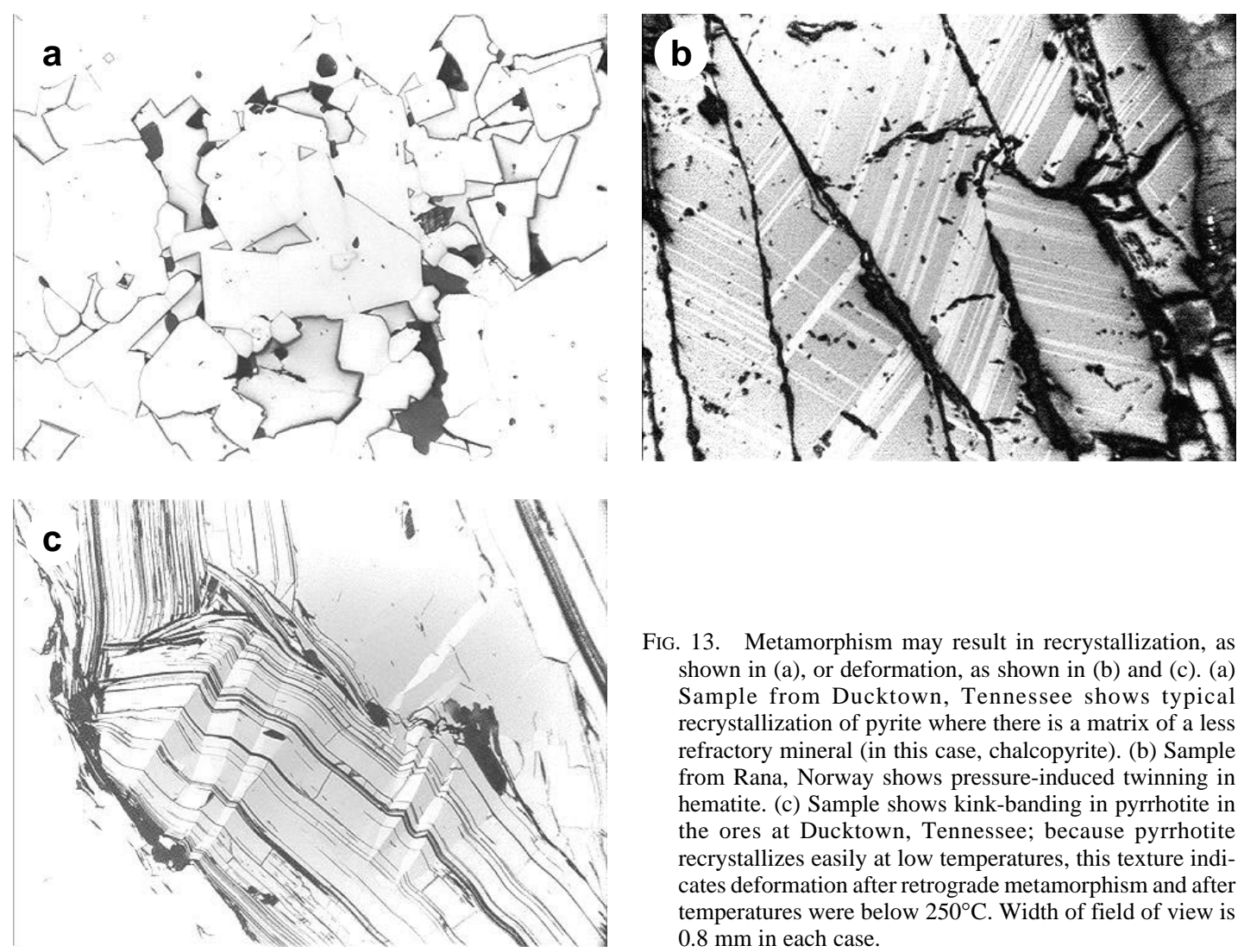

FIG. 13. Metamorphism may result in recrystallization, as shown in (a), or deformation, as shown in (b) and (c). (a) Sample from Ducktown, Tennessee shows typical recrystallization of pyrite where there is a matrix of a less refractory mineral (in this case, chalcopyrite). (b) Sample from Rana, Norway shows pressure-induced twinning in hematite. (c) Sample shows kink-banding in pyrrhotite in the ores at Ducktown, Tennessee; because pyrrhotite recrystallizes easily at low temperatures, this texture indicates deformation after retrograde metamorphism and after temperatures were below $250^{\circ} \mathrm{C}$. Width of field of view is $0.8 \mathrm{~mm}$ in each case. 
name derives from the Greek for "treacherous", and many mineralogists who have studied sphalerite will attest that the name is well deserved.

This brief account focuses on some recent studies of pyrite and the deposits in which it occurs. McClay \& Ellis (1983), Craig \& Vokes (1993), and Craig et al. (1998) provided additional information on its physical and chemical properties. The abundance of pyrite, its generally non-economic nature, and its refractory behavior have commonly led to its being overlooked as a potential reservoir of information for interpretation of the origins of ores. However, detailed examination of pyrite shows that it commonly incorporates mineral inclusions that may yield information on the occurrence of multiple episodes of mineral-forming fluids. Thus, pyrite in Figure 14a confirms that metamorphism had reached conditions sufficient to form amphibole before pyrite growth was complete. Furthermore, the presence of helical patterns of amphibole inclusions (Fig. 14b; Craig et al. 1991) confirms that rotational movement was occurring during pyrite growth.

More subtle, but potentially more informative, is the observation that pyrite from many types of deposits incorporates minor elements in well-defined zones, which may be enhanced by etching or defined by electronmicroprobe-based elemental mapping. Cobalt, nickel, and arsenic are commonly present in sufficient concentrations (up to hundreds of ppm) to be mapped easily with an electron microprobe using long counting-times and very high beam-currents (Craig et al. 1998). The pyrite of Figure 15a was deposited by fluids which, for one period transported nickel (as indicated by the white margin on earlier-formed pyrite. The pyrite formed both before and after contains much less nickel. The pyrite shown in Figure 15b recrystallized during high-grade metamorphism. An inner zone and the outer rim are enriched in arsenic and cobalt, indicating availability of these elements only during particular phases of metamorphism. This type of elemental mapping in pyrite from a Sudbury-type nickel deposit has shown that the history of cobalt availability is much more complex than previously known (Craig \& Solberg 2000).

Sphalerite has been the subject of a vast literature, but the focus here is in understanding the histories of some ore deposits. For discussions of sphalerite geothermometry, geobarometry, and speedometry, the reader is referred to summary works of Scott \& Barnes (1971), Scott (1976, 1983), Barton (1978), and Mizuta \& Scott (1997).

Sphalerite from many low-temperature deposits, especially Mississippi-Valley-type deposits, can record and retain compositional banding that reflects changes in the nature of the ore-forming fluids (Fig. 16a). Commonly, the banding is subtle and invisible megascopically, and cannot be seen in conventional polished sections viewed in reflected light. Such fine-scale banding (Fig. 16b) is commonly only visible when viewed in transmitted light using doubly polished thin sections. The value of such delicate compositional banding in the interpretation of ore deposits was first described by Barton et al. (1977) and then first extensively demonstrated by McLimans et al (1980). In addition to visible

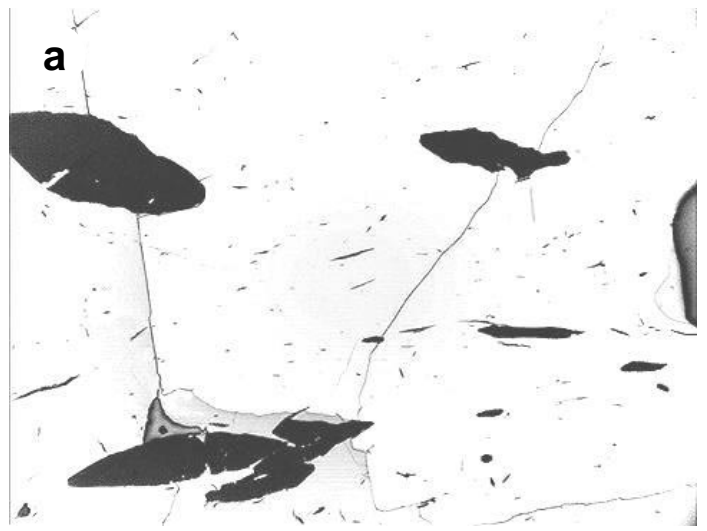

FIG. 14. Pyrite, the most abundant sulfide mineral, commonly contains textural features that can provide insight into the history of deposits. (a) Pyrite that has grown during metamorphism and engulfed previously formed laths of amphibole. (b) A 10-cm cube of pyrite that contains internal patterns of inclusions consistent with a full rotation during its growth during the metamorphic cycle. Both samples are from Ducktown, Tennessee; width of field in (a) is $0.8 \mathrm{~mm}$.

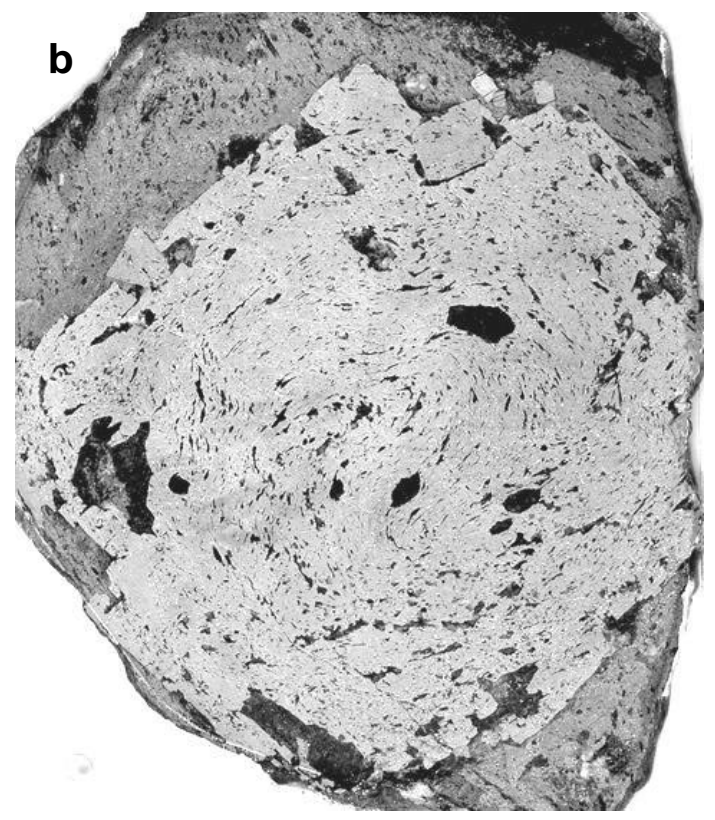




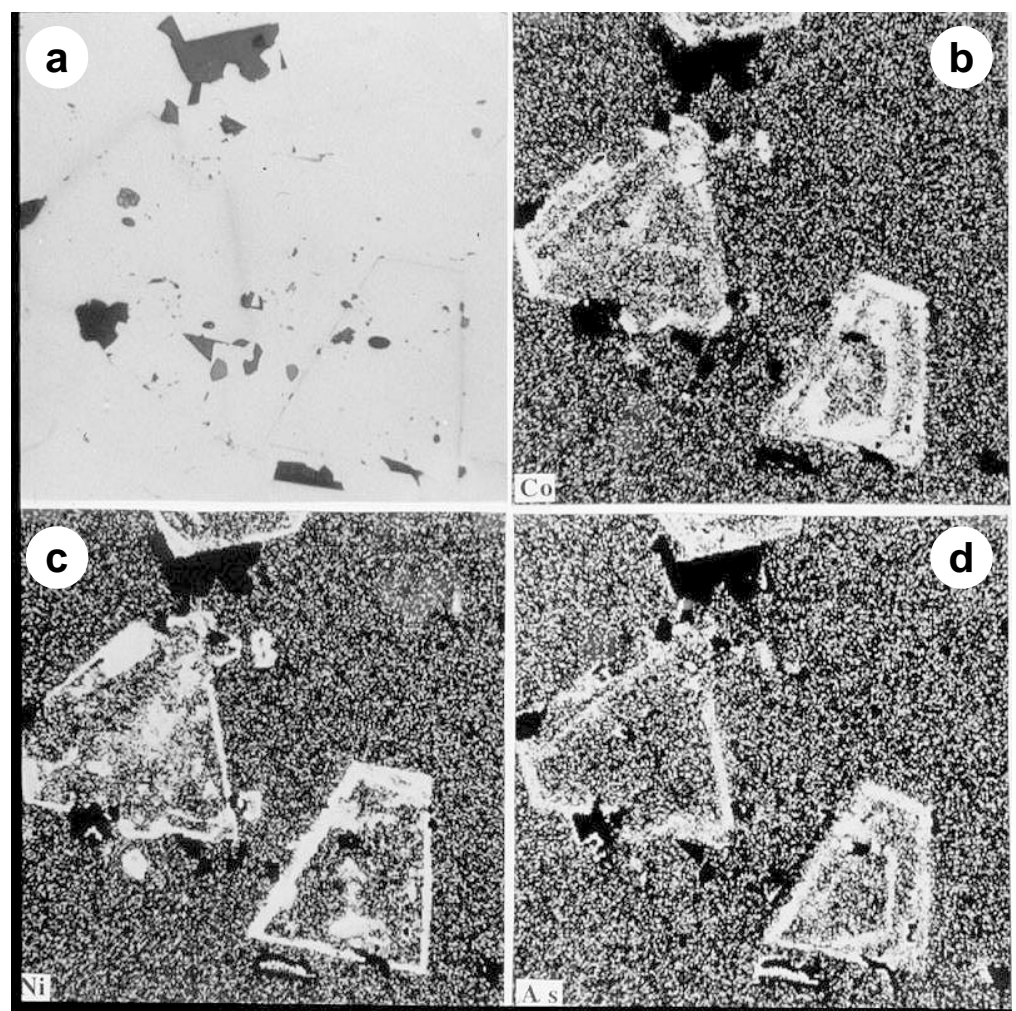

FIG. 15. (a) The only difference visible between two generations of pyrite in a sample from Wheal Jane, Cornwall, U.K., is a slight difference in hardness. However, elemental mapping of ore minerals with the electron microprobe may reveal significant variations in the distribution of chemical elements, indicating selective availability of the elements during the periods of growth. The maps of cobalt in (b), nickel in (c), and arsenic in (d) reveal that these elements were only available during the growth of the first generation of the pyrite. Field of view is $1.2 \mathrm{~mm}$ in all images.

microscopic studies, element mapping (Fig. 16c) may yield significant information on sequential incorporation of elements into sphalerite. Such chemical variations are commonly invisible in reflected or transmitted light, but may provide insights into the history of growth, the relationships between different generations of sphalerite and the irregular distribution of important trace elements.

Even though sphalerite is not sufficiently refractory to retain all of the original compositional integrity in many cases, it may still provide information that is useful in interpreting the history of ore deposits. For example, the sphalerite in Figure 17 has undergone significant alteration as the result of a second generation of hydrothermal activity. The remnants of the original sphalerite appear as uniform inclusion-free zones that contain approximately $9 \mathrm{wt} \% \mathrm{Fe}$. In contrast, the altered regions are flecked with marcasite, commonly crystallographically controlled, that has formed as iron was extracted from the sphalerite and reacted with a more sulfur-rich fluid. Consequently, the altered sphalerite contains only about $0.5 \mathrm{wt} \% \mathrm{Fe}$. The altered sphalerite and secondary marcasite tell much about the nature of the later invading fluid, and the boundaries of the marcasite show the limit of fluids reaction.

\section{Tales of gold}

Gold, the very symbol of wealth, has been the focus of more of man's attention than any other metal. Unfortunately, the history of gold has been tainted with numerous schemes that have played upon the desire for rapid riches. The old definition of "a gold mine is a hole in the ground with a liar at the top" has been demonstrated far too often. The 1990s saw the most recent, and probably largest, of these schemes in the Bre-X operations at Busang, Indonesia; the complete story is well documented by Danielson \& Whyte (1997). The 

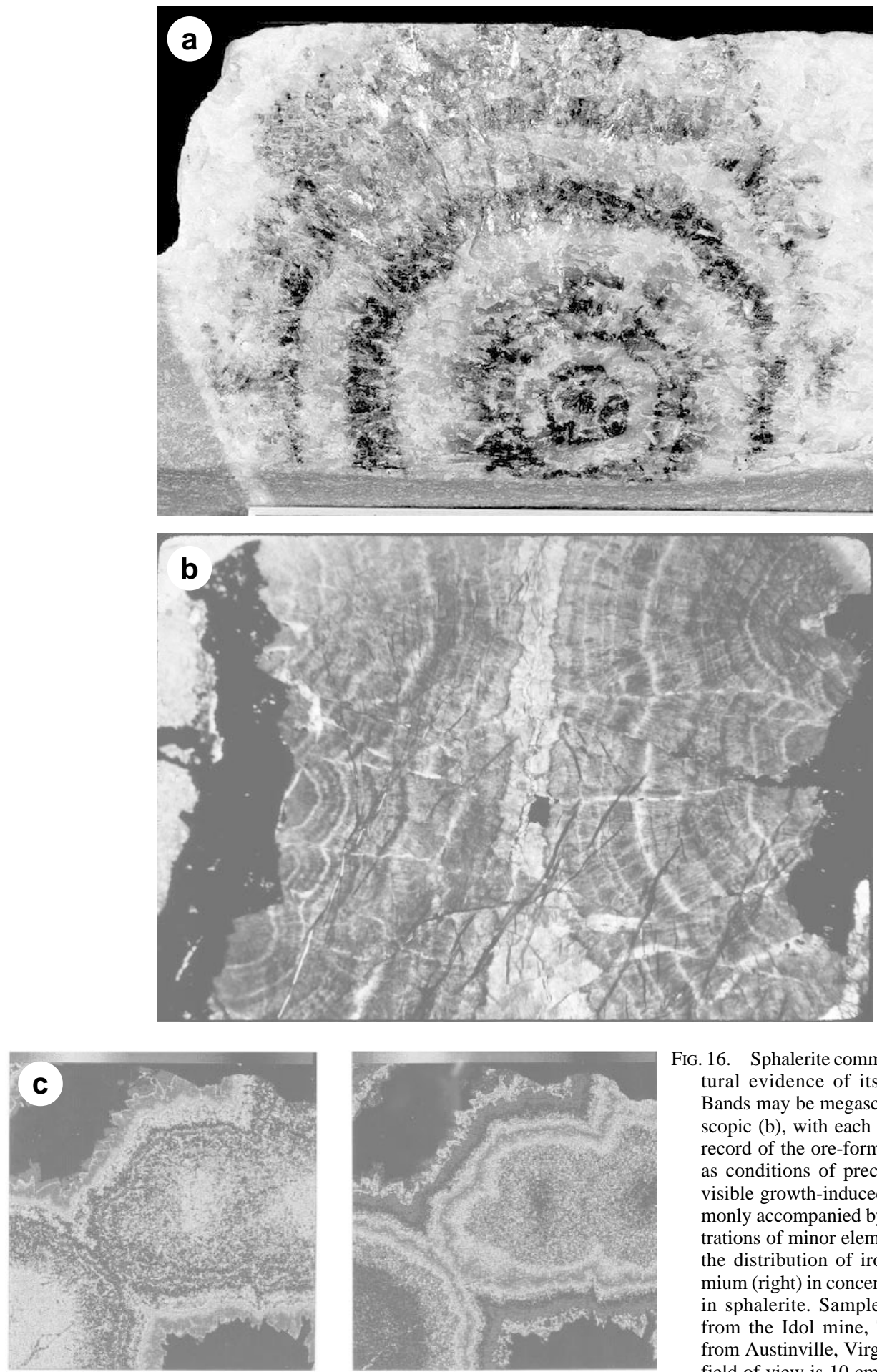

FIG. 16. Sphalerite commonly contains textural evidence of its growth history. Bands may be megascopic (a) or microscopic (b), with each band preserving a record of the ore-forming fluids as well as conditions of precipitation. (c) The visible growth-induced banding is commonly accompanied by variable concentrations of minor elements, as shown by the distribution of iron (left) and cadmium (right) in concentric growth-zones in sphalerite. Samples (a) and (c) are from the Idol mine, Tennessee; (b) is from Austinville, Virginia. Width of the field of view is $10 \mathrm{~cm}$ in (a), $0.6 \mathrm{~mm}$ in (b), and $2 \mathrm{~mm}$ in (c). 


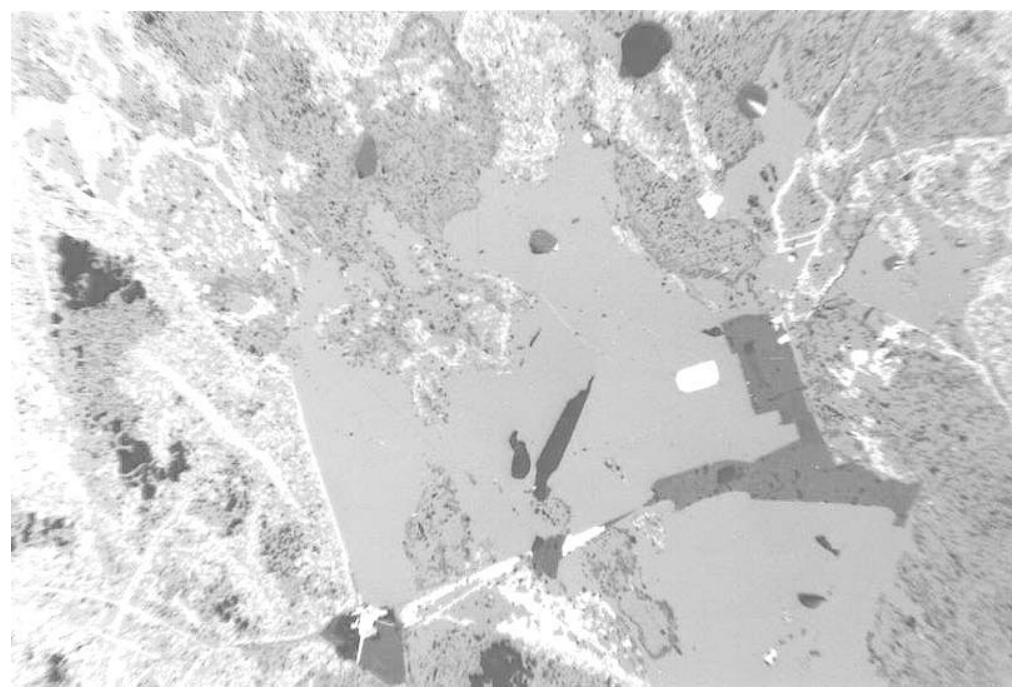

FIG. 17. Even altered sphalerite can reveal information about its history and the nature of conditions of its alteration. The initial, and relatively featureless, sphalerite is homogeneous and contains approximately $9 \mathrm{wt} \%$ Fe. Invasion of a later fluid, with a higher activity of sulfur, altered the sphalerite, creating much porosity and dispersed fine grains of marcasite. The alteration selectively removed iron from the sphalerite to form marcasite and the pore spaces, and left the remaining sphalerite with only $0.5 \mathrm{wt} \% \mathrm{Fe}$. The sample is from Mashan, China. Field of view is $0.8 \mathrm{~mm}$.

undoing of the scheme was in no small measure dependent on the tales told by gold textures. Primary gold deposited in all types of lode deposits is nearly always uniform in composition throughout each grain (Fig. 18a). In contrast, numerous studies of placer gold (e.g., Groen et al. 1990) have shown that individual placer grains, when examined in cross section in reflected light, very commonly contain a well-developed rim of nearly pure gold extending partly or completely around a core of lower-fineness gold (Fig. 18b). Although the mechanisms of formation remain a subject of debate, it is clear that these rims may develop in a wide variety of geochemical environments. Because these rims are common on placer grains, it is not possible to rely on surficial analysis of placer grains to ascertain their actual internal composition. Only where grains have been sectioned, revealing their interiors, can one be certain of the actual internal compositions and whether there may be evidence of their presence in a placer deposit at some time in their history. Elemental mapping of gold and silver distributions (Fig. 18c) commonly reveals even more clearly how gold-rich rims have developed on grains of placer gold.

The duly diligent examination of the Bre-X deposit included careful microscopic examination of the supposed lode gold in some of the ore samples. Danielson \& Whyte (1997) reported that "it was the shape, not the size, of the gold grains that stood out ... rounded with beaded outlines ... rounding and beading are characteristic of placer grains .... some of these ... gold grains had cores of gold-silver alloy, which graded outward to a rim with more gold. This was another clue: 'hardrock gold', more often than not, is actually an alloy containing some silver. But when the grains are re-concentrated as placers, ... the silver reacts with air and water, leaching away and leaving a spongy, gold rich edge". Indeed, the placer gold used to "salt" the Bre-X cores bore the characteristic textural signature attesting to its origin, and helped in revealing the scam for what it was.

A different tale of gold is shown in Figure 19, in which gold grains are coated with magnetite. According to stories from the gold rushes in Alaska, samples such as this were separated from placer gold as worthless magnetic materials and collected into barrels. Only some time later did someone realize that the magnetic materials actually commonly coated gold grains and that a considerable fortune had been missed by the original miners. Whether the story is true of not, the texture reveals a plausible tale where employment of the wrong technique of separation could be costly.

\section{Tales of corrosion}

The study of the corrosion of metals was long left in the hands of metallurgists, but in recent years ore mineralogists have recognized that many corrosion phenom- 

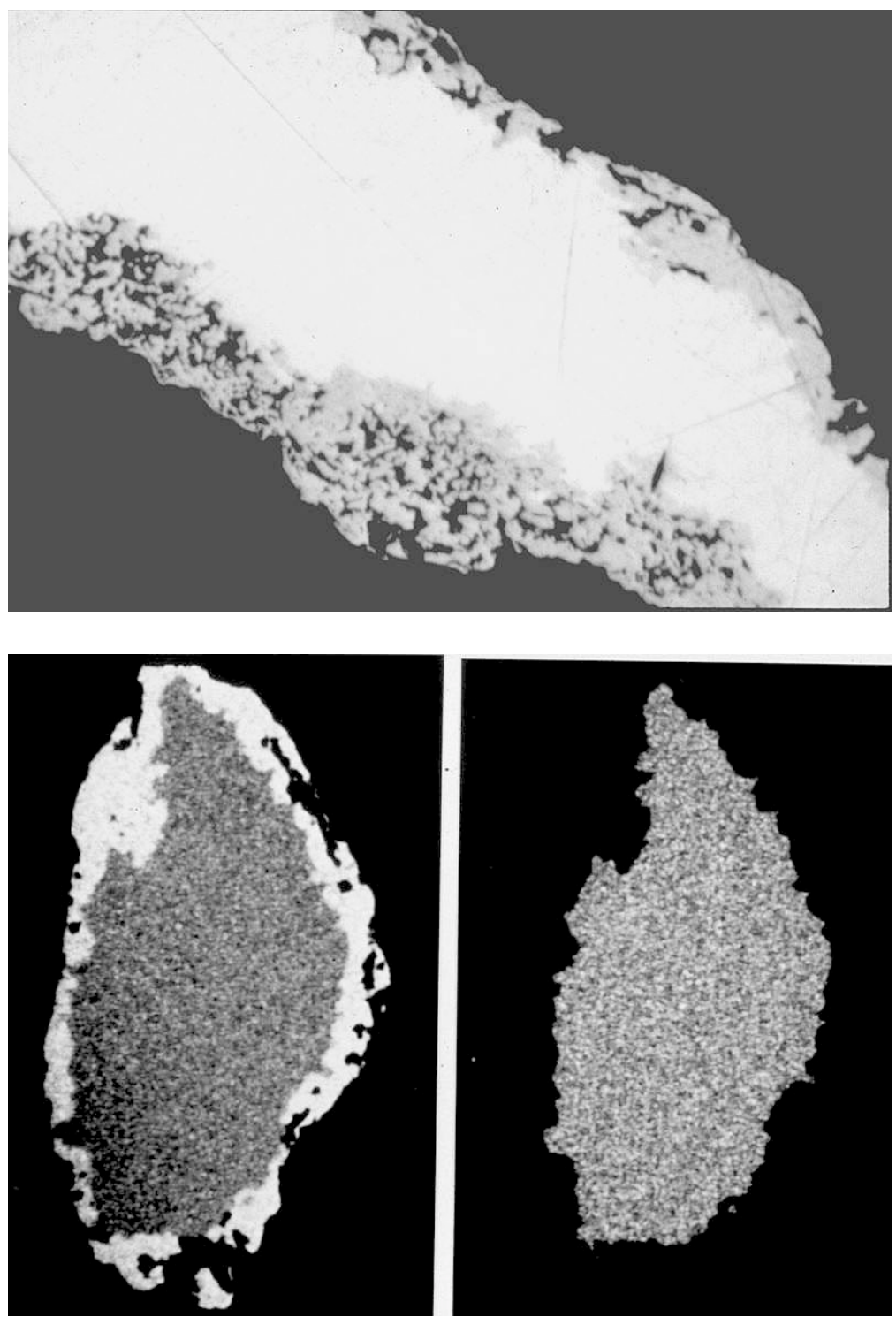

Fig. 18. Textures of gold grains may provide evidence of their origin and history. Where precipitated from a hydrothermal fluid, gold grains are generally homogeneous. In contrast, placer grains from a wide variety of environments typically exhibit a well-defined gold-rich rim. The upper optical light image reveals a well-developed gold-rich rim on a placer grain. The lower gold (left) and silver (right) X-ray maps made with the electron microprobe confirm the high purity of gold and the absence of silver in the rim. The presence of such rims in samples from the Busang deposit in Indonesia helped confirm that the deposit had been salted. The widths of the fields of view are $0.8 \mathrm{~mm}$.

ena are appropriate subjects for applied ore mineralogy. The corrosion process is in many cases a mini-experiment in which ore minerals and their analogues are forming in much the same manner as syngenetic ores; the principal difference is that the metal is derived from a local source, such as a weathering pipe, coin, or artifact, instead of an unknown distant source. Examples of corrosion discussed here involve coins from 18th and 


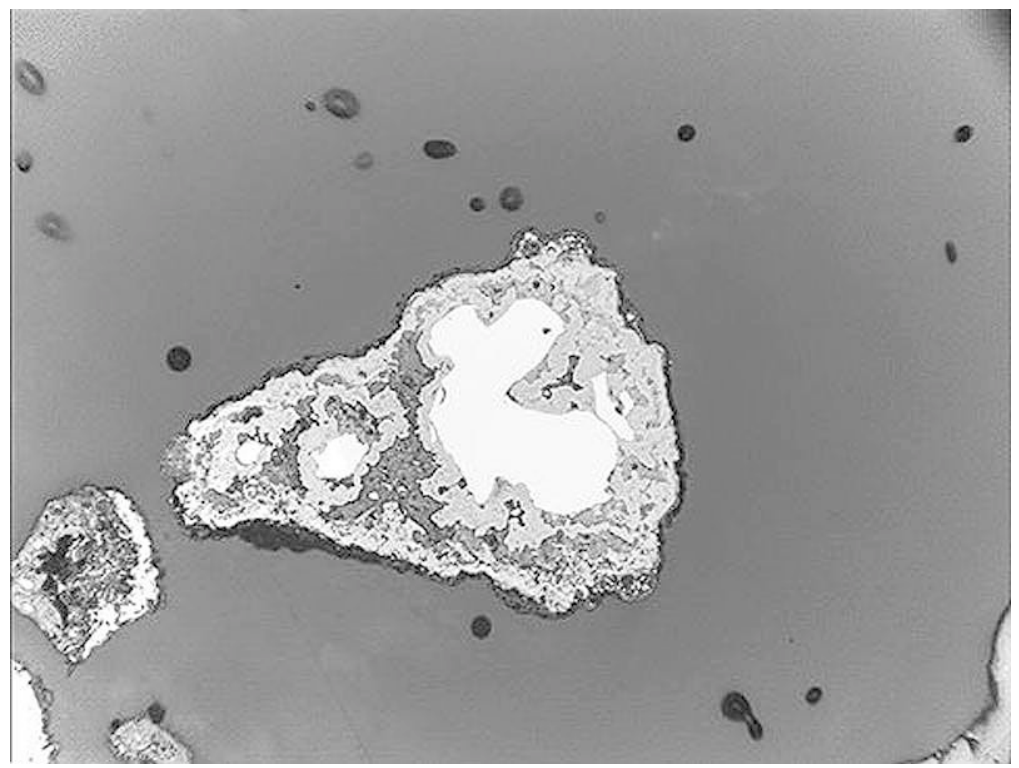

FIG. 19. Gold grains from some Alaskan placers are encased in magnetite, and were discarded as useless when magnets were used to separate gold from what was believed to be worthless magnetic materials. The width of the field of view is $0.8 \mathrm{~mm}$ across.

19th Century sunken Spanish galleons. The first example is a Spanish Piece of Eight, or Eight Real Piece, minted in 1800 in Lima, Peru, and which went down with the Santa Leocadia off the coast of Ecuador in 1827. It lay on the sea floor until it was recovered by American military men stationed in Ecuador in the 1940s. The coin was completely encased in a mass of detritus and recognizable as a coin only because of its shape and proximity to other coins that were not so corroded. Preparation of a polished section showed the $90 \%$ silver, $10 \%$ copper coin was surrounded by layers of corrosion products and a shell of detrital fragments completely cemented by silver and copper sulfides (Fig. 20a). The sulfur was presumably derived from seawater sulfate by bacterial reduction in the surrounding sediments. The bulk of the corrosion products consists of copper-bearing acanthite with local disseminations of covellite and mckinstryite (Fig. 20b). In addition, there is local replacement of residual shell fragments in whole or in part by atacamite. Preliminary studies of another coin, a four Real coin, which lay in the wreck of the Infante from 1733 until the 1980s, showed a somewhat similar pattern of corrosion, with cementation of surrounding sediment and development of concentric corrosion-induced rims. The dissolution of silver and its subsequent reprecipitation have not only incorporated sand grains but also some fragments of marine biota (Figs. 21a and b).

\section{Ore minerals and analogues in pollution}

The ore minerals have served as our sources of metals for thousands of years. Today, some of the same minerals and various anthropogenic (at least in part) analogues may be viewed as pollutants. Pyrite, although rarely a valued mineral in most ore deposits, has become the focus of considerable attention because it is so often responsible for the generation of significant amounts of acid, which may severely damage soils and waterways. The billions of tonnes of coal waste and old mine tailings that now lie exposed continue to release large quantities of acid and can simultaneously release a variety of metals into the environment.

Lead is a metal which, despite it use by humankind for millennia, is toxic to humans and wildlife. Studies of some of the lead materials and their corrosion phases are yielding tales that continue to unfold. For example, expended lead munitions of the types widely used in hunting and recreational shooting throughout the world have prompted detailed examinations of the nature of the corrosion phases that develop on surfaces as the lead lies in soils and waterways. In the United States, the total amount of lead released into the environment has been more than four million tonnes in the 20th Century (based on data of the U.S. Bureau of Mines and U.S. Geological Survey). No doubt, proportionately large quantities have been released by similar activities in many parts of the world. Figure 22a shows how corrosion layers of 

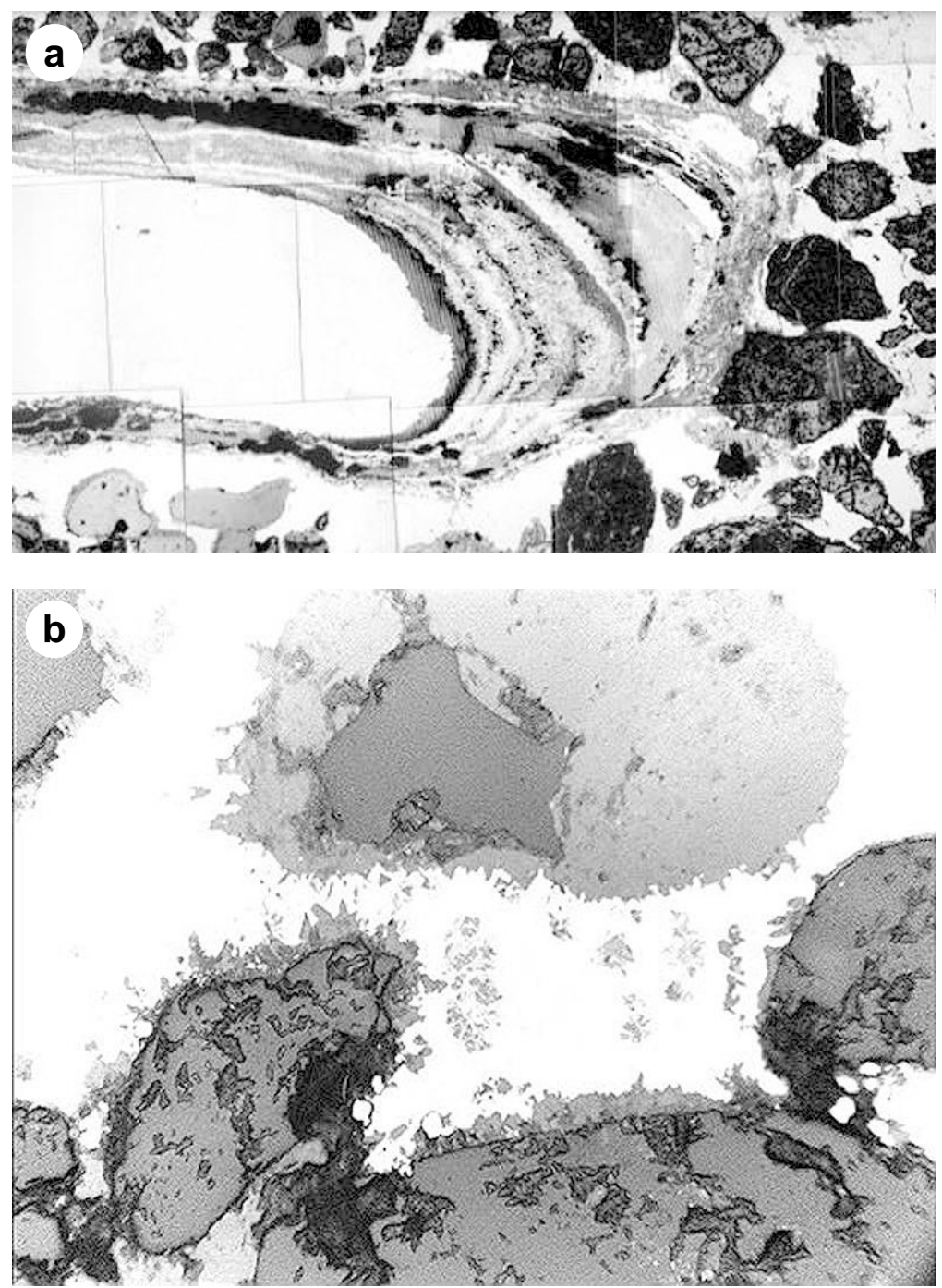

FIG. 20. Corrosion of human-refined metals produces mineral analogues and textures that mimic those of natural ore deposits. (a) A photocollage of an approximately 7-mm-long section of a Spanish Piece-of-Eight, showing the original silver-copper alloy coin and the surrounding zones cemented by acanthite. (b) There are dispersed small grains of covellite in a matrix of acanthite, and some larger rounded light gray grains of atacamite that have replaced pre-existing grains of calcite. The field of view of (b) is $0.8 \mathrm{~mm}$.

lead oxides and carbonates develop around the margins of expended weathering shotgun pellets. Figure $22 \mathrm{~b}$ shows how initially inhomogeneous shot, hardened by the addition of small amounts of arsenic, antimony, and copper, weathers selectively such that the lead (the light phase in the center of the small pillow-like structures) is converted into lead carbonates (darker filling of the same structures) near the weathered margin. The photomicrographs also show that the interstitial phase, enriched in the other metals, remains more resistant to weathering. The somewhat comforting tale here is that the lead does, indeed, react rapidly to form corrosion layers; however, the secondary phases forming are less soluble than the lead and hence serve to significantly 

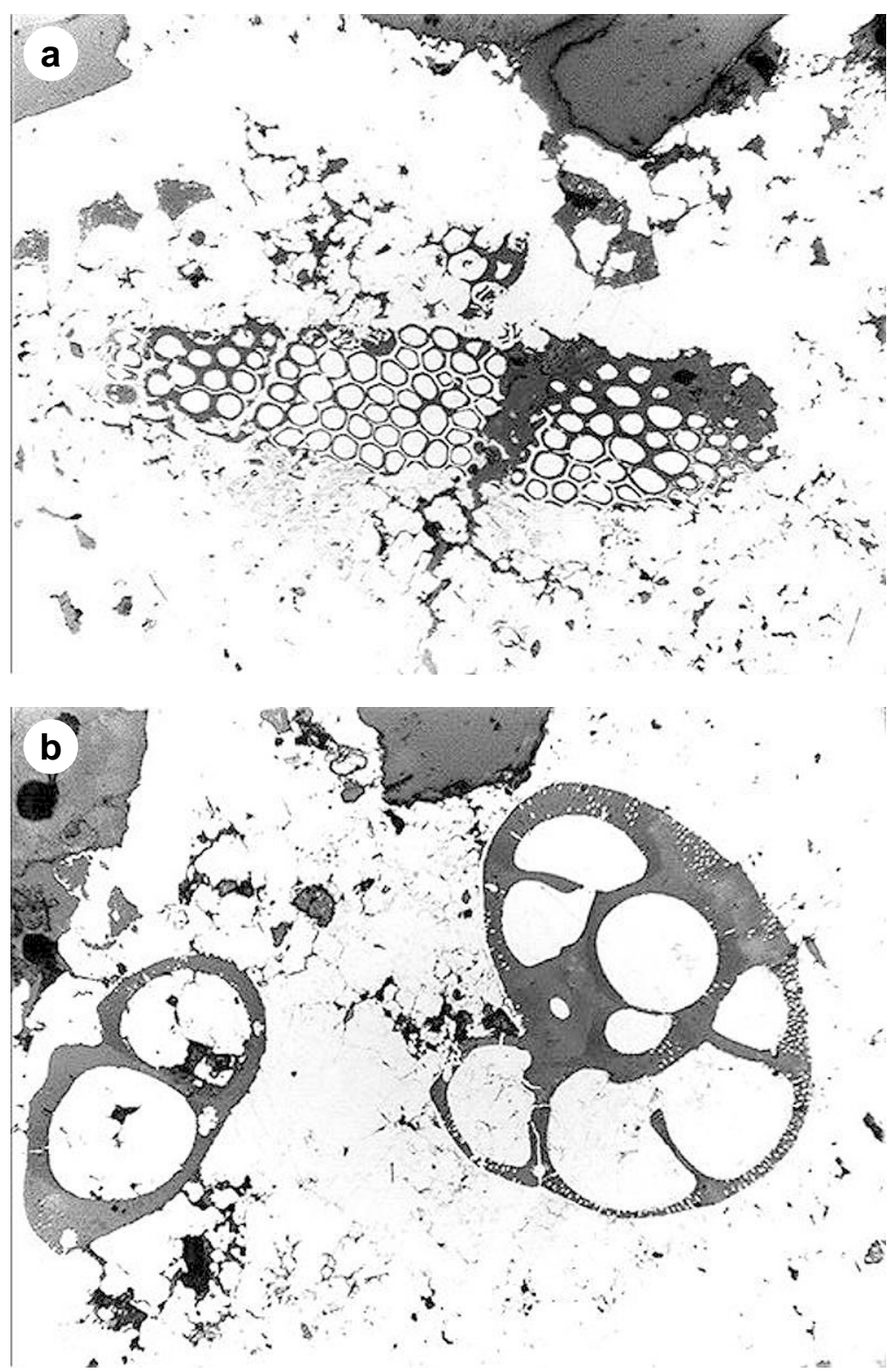

FIG. 21. Corrosion of a Spanish Four Real coin, recovered from the wreck of the Infante (sunk in 1733), has resulted in formation of acanthite, which has cemented and infilled bryozoan structures (a) and foraminifera (b). The field of view is $0.8 \mathrm{~mm}$ in both photos.

reduce the release of lead into the environment. Furthermore, the other metals seem to be less reactive than lead and are retained in the weathering rind of the munitions rather than being released during weathering.

\section{Concluding Comments}

Ore minerals, valuable as they are to modern society, can actually yield more than just metal. Their textures, like words in a book, commonly record the history 

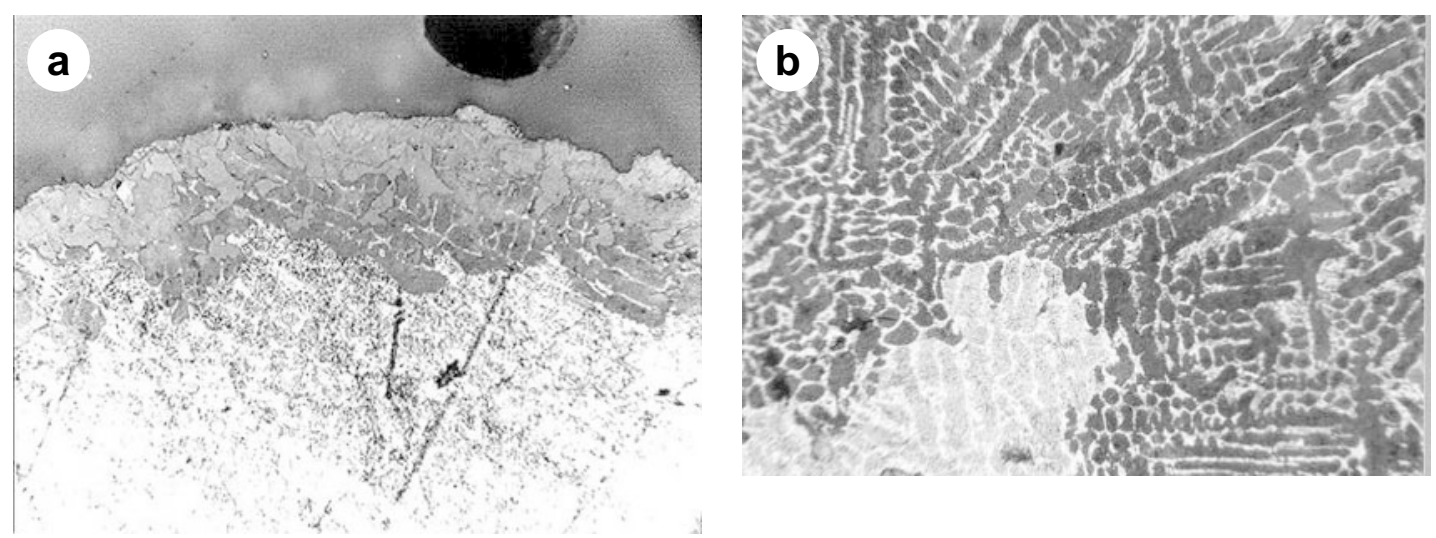

FIG. 22. Corrosion of lead shot and bullets, expended in hunting or recreational shooting, results in formation of mineral analogues. (a) Concentric layers of lead hydroxycarbonate forming on the surface of a lead shotgun pellet. (b) The selective oxidation of this material (dark areas) forming lead oxides; this leaves the whiter interstitial zones that contain the hardening agents unaltered. The corrosion layers armor the lead in the interior and reduce the environmental availability of lead. The field of view is $1.2 \mathrm{~mm}$ in both cases.

of ore deposition and subsequent changes that may have occurred in responses to changing physical and chemical conditions during and after deposition. Accordingly, detailed study of ore minerals, from the macro- to the micro-scale, may lead to the deciphering of their origins, and thus aid in the search for new ores, and new ways of optimizing the extraction of metals. In corrosion and pollution, the behavior of metals mimics the processes of ore formation and alteration. Consequently, the textures developed by such processes may be interpreted in similar ways and, conversely, can provide insight into processes of ore formation. Ore-mineral textures have many tales to tell; we must learn to read them carefully and learn to decipher them effectively.

\section{ACKNOWLEDGEMENTS}

I am grateful to the IMA for offering me the opportunity to present the Plenary Talk, from which this paper was derived, and the push to actually put it into a text form. The ideas expressed herein have accumulated and developed over many years, and are certainly due to contributions from, and conversations with, more individuals than I can even remember. Of special note are Gunnar Kullerud, who introduced me to the ore minerals, Tony Naldrett, who helped hone my skills, David Vaughan, who helped me to write books, and Frank Vokes, who greatly expanded my repertoire. I am also much in debt to the Department of Geology, University of St. Andrews, Scotland, who invited me to serve as the C.F. Davidson Memorial Lecturer in 1994. My talk there on "Ore minerals from macroscale to microscale" served as the original basis for the IMA talk and this paper. I am much in debt to David Vaughan and John Callahan, who served as reviewers, and Frank C.
Hawthorne, whose editorial skills reduced the length of the paper and made it more clear.

\section{REFERENCES}

Barton, P.B. (1970): Sulfide petrology. Mineral. Soc. Am., Spec. Pap. 3, 187-198.

(1978): Some ore textures involving sphalerite from the Furutobe mine, Akita Prefecture, Japan. Mining Geol. (Japan) 28, 293-300.

(1991): Ore textures: problems and opportunities. Mineral. Mag. 55, 303-315.

\& BethKe, P.M. (1987): Chalcopyrite disease in sphalerite: pathology and epidemiology. Am. Mineral. 72, 451-467.

\& ROEDDER, E. (1977): Environment of ore deposition in the Creede mining district, San Juan Mountains, Colorado. III. Progress toward interpretation of the chemistry of the ore-forming fluid for the $\mathrm{OH}$ vein. Econ. Geol. 72, 1-24.

BASTIN, E.S. (1950): Interpretation of ore textures. Geol. Soc. Am., Mem. 45.

CRAIG, J.R. (1991a): Textures of the ore minerals. In Advanced Microscopic Studies of Ore Minerals (J.L. Jambor \& D.J. Vaughan, eds.). Mineral. Assoc. Can., Short-Course Notes 17, 213-261.

(1991b): Ore textures and paragenetic studies - some modern case histories and sources of comparative data. In Advanced Microscopic Studies of Ore Minerals (J.L. Jambor \& D.J. Vaughan, eds.). Mineral. Assoc. Can., Short-Course Notes 17, 263-317. 
(2001): Metals. In Encyclopedia of Global Change (A.S. Goudie, ed.). Oxford University Press, New York, N.Y. $(2,76-84)$.

\& SolBerg, T.N. (1999): Compositional zoning in ore minerals at the Craig mine, Sudbury, Ontario, Canada. Can. Mineral. 37, 1163-1176.

\& VAughan, D.J. (1994): Ore Microscopy and Ore Petrography (second ed.). Wiley Interscience, New York, N.Y.

\& VoKes, F.M. (1993): The metamorphism of pyrite and pyritic ores: an overview. Mineral. Mag. 57, 3-18.

\& SiMPSON, C. (1991): Rotational fabrics in pyrite from Ducktown, Tennessee. Econ. Geol. 86, 1737 1746.

\& Solberg, T.N. (1998): Pyrite: physical and chemical textures. Mineral. Deposita 34, 82-101.

Danielson, V. \& Whyte, J. (1997): Bre-X: Gold Today, Gone Tomorrow: Anatomy of the Busong Swindle. The Northern Miner, Toronto, Ontario.

EDwARDs, A.B. (1946): Textures of the Ore Minerals. Australian Institute of Mining and Metallurgy, Melbourne, Australia.

Eldridge, C.S., BARTon, P.B. \& Oнмото, H. (1983): Mineral textures and their bearing on the formation of the Kuroko orebodies. Econ. Geol., Monogr. 5, 241-281.

Groen, J.C., Craig, J.R. \& Rimstidt, J.D. (1990): Gold-rich rim formation on electrum grains in placers. Can. Mineral. 28. 207-228.

IXER, R.A. (1990): Atlas of Opaque and Ore Minerals in Their Associations. Von Nostrand Rheinhold, New York, N.Y.

KelLy, W.C. \& CLARK, B.R. (1975): Sulfide deformation studies. III. Experimental deformation of chalcopyrite to 2000 bars and $500^{\circ} \mathrm{C}$. Econ. Geol. 70, 432-453.

McClay, K.R. \& Ellis, P.G. (1983): Deformation and recrystallization of pyrite. Mineral. Mag. 47, 527-538.

Mclimans, R.K., Barnes, H.L. \& Ohmoto, H. (1980): Sphalerite stratigraphy of the upper Mississippi Valley zinc-lead district, southwest Wisconsin. Econ. Geol. 75, 351-361.

MizutA, T. \& ScotT, S.D. (1997): Kinetics of iron depletion near pyrrhotite and chalcopyrite inclusions in sphalerite: the sphalerite speedometer. Econ. Geol. 92, 772-783.

RAMdohr, P. (1969): The Ore Minerals and Their Intergrowths. Pergamon Press, New York, N.Y.

ScotT, D.A. (1991): Metallography and Microstructure of Ancient and Historic Metals. The Getty Conservation Institute, Marina del Rey, California.

ScotT, S.D. (1976): Application of sphalerite geobarometry to regionally metamorphosed terrains. Am. Mineral. 61, 661670 .

(1983): Chemical behaviour of sphalerite and arsenopyrite in hydrothermal and metamorphic environments. Mineral. Mag. 47, 427-435.

\& BARNES, H.L. (1971): Sphalerite geobarometry and geothermometry. Econ. Geol. 66, 653-669.

Stumpfl, E., Reimann, C., Gregurek, D. \& CheKushi, V.A. (1997): Environmental mineralogy in the Kola project: sulfides, oxides, alloys and silicates in filter residues from snow samples. In Symp. on Formation and Metamorphism of Massive Sulfides (Trondheim), 27.

U.S. Geological Survey (1999): Statistical Summary, Mineral Industry Surveys. Dept. of the Interior, Government Printing Office, Washington, D.C.

VAUGHAN, D.J. \& CRAIG, J.R. (1997): Sulfide ore mineral stabilities, morphologies, and intergrowth textures. In Geochemistry of Hydrothermal Ore Deposits (H.L. Barnes, ed.; third edition). Wiley Interscience, New York, N.Y. (367-434).

VOKES, F.M. (1969): A review of the metamorphism of sulphide deposits. Earth-Sci. Rev. 5, 99-143.

Received December 1, 1999, revised manuscript accepted July 3, 2001. 